\title{
Framework for a Hydrologic Climate-Response Network in New England
}

Open-File Report 2015-1062 



\section{Framework for a Hydrologic Climate- Response Network in New England}

By Robert M. Lent, Glenn A. Hodgkins, Robert W. Dudley, and Luther F. Schalk

Open-File Report 2015-1062 


\title{
U.S. Department of the Interior SALLY JEWELL, Secretary
}

\section{U.S. Geological Survey Suzette M. Kimball, Acting Director}

\author{
U.S. Geological Survey, Reston, Virginia: 2015
}

For more information on the USGS - the Federal source for science about the Earth, its natural and living resources, natural hazards, and the environment—visit http://www.usgs.gov or call 1-888-ASK-USGS.

For an overview of USGS information products, including maps, imagery, and publications, visit http://www.usgs.gov/pubprod/.

Any use of trade, firm, or product names is for descriptive purposes only and does not imply endorsement by the U.S. Government.

Although this information product, for the most part, is in the public domain, it also may contain copyrighted materials as noted in the text. Permission to reproduce copyrighted items must be secured from the copyright owner.

Suggested citation:

Lent, R.M., Hodgkins, G.A., Dudley, R.W., and Schalk, L.F., 2015, Framework for a hydrologic climate-response network in New England: U.S. Geological Survey Open-File Report 2015-1062, 34 p., http://dx.doi.org/10.3133/ofr20151062.

ISSN 2331-1258 (online) 


\section{Contents}

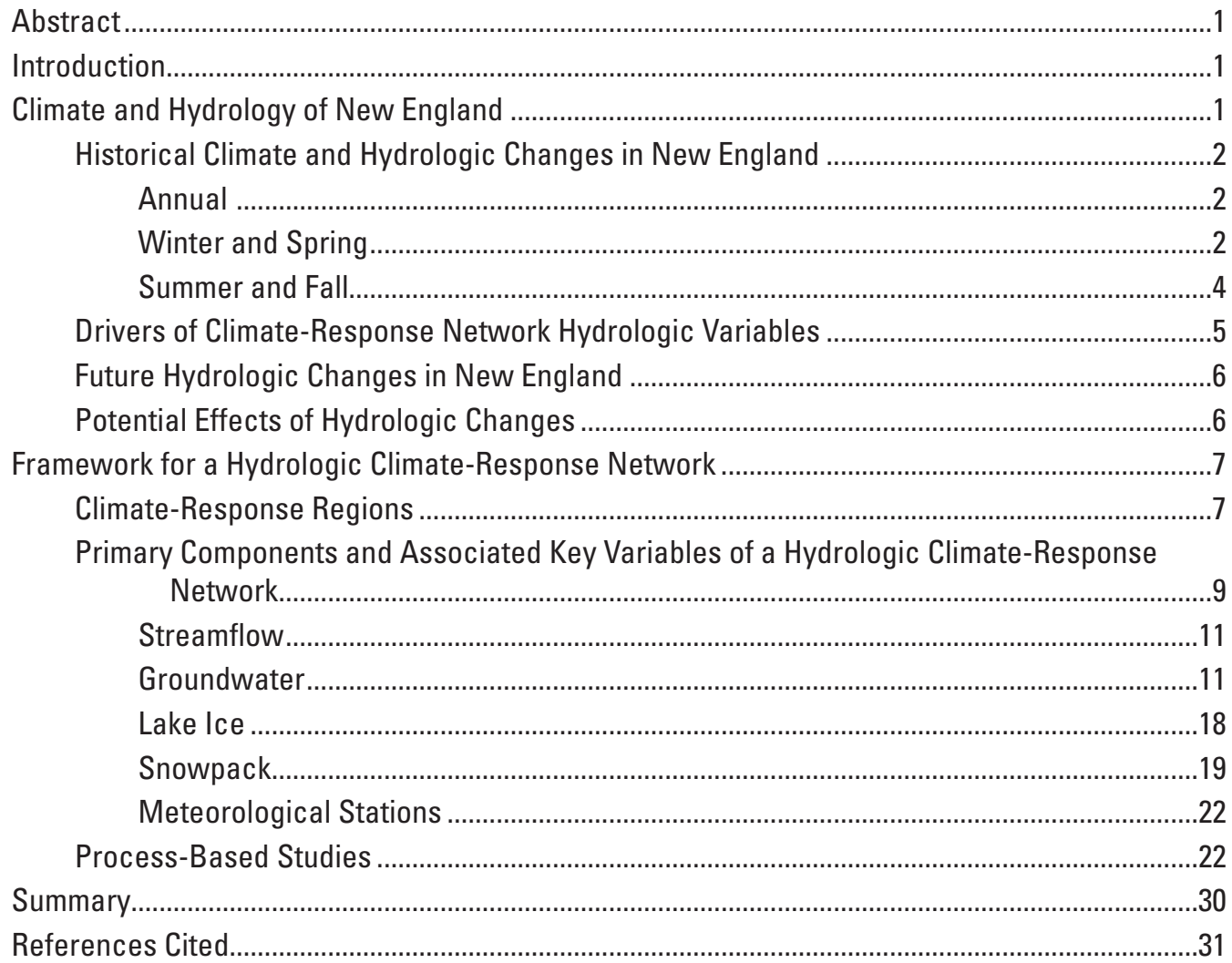

\section{Figures}

1. Graph showing historical winter-spring streamflow timing for the Piscataquis River in central Maine ..........................................................................................................

2. Graph showing historical ice-out dates for Damariscotta Lake in midcoastal Maine .....5

3. Map showing hydrologic climate-response regions in New England ............................8

4. Smoothed plots of winter-spring streamflow timing for streams in New England..........10

5. Smoothed plots of historical lake ice-out dates in New England .................................10

6. Map showing streamflow-gaging stations in New England that drain relatively natural watersheds ..................................................................................................12

7. Map showing groundwater wells in New England minimally affected by human

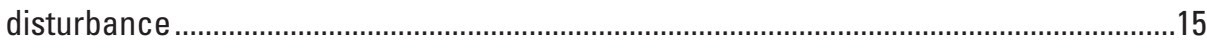

8. Graph showing relation of August groundwater levels and annual mean

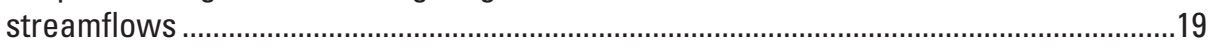

9. Map showing lakes in New England with substantial amounts of ice-out data..............20

10. Map showing location of long-term snowpack sites in New England ............................23

11. Map showing U.S. Historical Climatology Network meteorological stations in New England ... 
12. Map showing basin sites appropriate for process-based studies

13. Map showing an example of rainfall-runoff-model subareas for two basins in eastern coastal Maine.

\section{Tables}

1. Annual and seasonal climatic drivers of hydrologic variability in New England ..............5

2. Description of hydrologic climate-response regions in New England...............................9

3. Streamflow-gaging stations in New England that drain relatively natural watersheds.

4. Groundwater wells in northern New England that meet climate-network criteria.........16

5. Lakes in New England with substantial amounts of ice-out data ...................................21

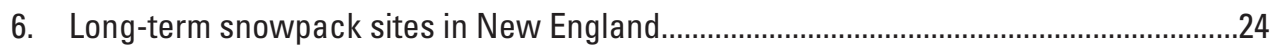

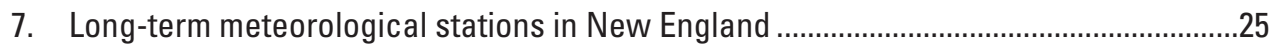

8. Basin sites appropriate for process-based studies.........................................................

\section{Conversion Factors}

Inch/Pound to International System of Units

\begin{tabular}{lcl}
\hline \multicolumn{1}{c}{ Multiply } & By & \multicolumn{1}{c}{ To obtain } \\
\hline inch (in.) & Length & \\
mile (mi) & 2.54 & centimeter $(\mathrm{cm})$ \\
& 1.609 & kilometer $(\mathrm{km})$ \\
\hline square mile $\left(\mathrm{mi}^{2}\right)$ & Area & \\
square mile $\left(\mathrm{mi}^{2}\right)$ & 259.0 & hectare $($ ha $)$ \\
& 2.590 & square kilometer $\left(\mathrm{km}^{2}\right)$ \\
\hline cubic foot per second $(\mathrm{ft} 3 / \mathrm{s})$ & Flow rate & \\
inch per year $(\mathrm{in} / \mathrm{yr})$ & 0.02832 & cubic meter per second $\left(\mathrm{m}^{3} / \mathrm{s}\right)$ \\
\hline
\end{tabular}

Temperature in degrees Fahrenheit $\left({ }^{\circ} \mathrm{F}\right)$ may be converted to degrees Celsius $\left({ }^{\circ} \mathrm{C}\right)$ as ${ }^{\circ} \mathrm{C}=(\mathrm{F}-32) / 1.8$.

\section{Datum}

Vertical coordinate information is referenced to the North American Vertical Datum of 1988 (NAVD 88).

Horizontal coordinate information is referenced to the North American Datum of 1983 (NAD 83).

Elevation, as used in this report, refers to distance above the vertical datum. 


\section{Abbreviations}

$\begin{array}{ll}\text { GAGES II } & \text { Geospatial Attributes of Gages for Evaluating Streamflow, version II } \\ \text { GCM } & \text { general circulation model } \\ \text { HCDN-2009 } & \text { Hydro-Climatic Data Network 2009 } \\ \text { MGS } & \text { Maine Geological Survey } \\ \text { PRMS } & \text { Precipitation-Runoff Modeling System } \\ \text { USGS } & \text { U.S. Geological Survey } \\ \text { USHCN } & \text { U.S. Historical Climatology Network } \\ \text { WSCV } & \text { winter-spring center of volume } \\ \text { WSV } & \text { winter-spring runoff volume }\end{array}$





\title{
Framework for a Hydrologic Climate-Response Network in New England
}

\author{
By Robert M. Lent, Glenn A. Hodgkins, Robert W. Dudley, and Luther F. Schalk
}

\begin{abstract}
Many climate-related hydrologic variables in New England have changed in the past century, and many are expected to change during the next century. It is important to understand and monitor these changes because they can affect human water supply, hydroelectric power generation, transportation infrastructure, and stream and riparian ecology. This report describes a framework for hydrologic monitoring in New England by means of a climate-response network. The framework identifies specific inland hydrologic variables that are sensitive to climate variation; identifies geographic regions with similar hydrologic responses; proposes a fixedstation monitoring network composed of existing streamflow, groundwater, lake ice, snowpack, and meteorological datacollection stations for evaluation of hydrologic response to climate variation; and identifies streamflow basins for intensive, process-based studies and for estimates of future hydrologic conditions.
\end{abstract}

\section{Introduction}

Seasonal, annual, and longer term variations in precipitation and air temperature can affect the timing and magnitude of numerous hydrologic processes that, in turn, affect natural resources, ecosystems, and society. Recent investigations conclude that many different hydrologic processes in New England are sensitive to variations in precipitation and air temperature. Various hydrologic variables, such as peak flows and the timing of winterspring streamflows, have changed during the last century and are expected to change in the future. Observed trends during winter and spring are largely related to changes in air temperature because of the sensitivity of snowpack to air temperature changes in New England. Trends during summer and fall are largely related to changes in precipitation.

The U.S. Geological Survey (USGS) published a framework for a hydrologic climate-response network in Maine (Hodgkins and others, 2009). The framework benefitted from a decade of climate-change-related investigations into many components of the water cycle in Maine and New England and demonstrated how relevant hydrologic data describing various components of the regional water cycle can be key indicators of climate change. This report expands the Maine framework to cover the New England region-a larger, more climatologically diverse area with a much greater population than Maine. The New England framework has four purposes:

- Identify specific hydrologic variables for inland areas that are sensitive to climate variation.

- Identify geographic regions with similar hydrologic responses.

- Propose a fixed-station monitoring network composed of existing streamflow, groundwater, lake ice, snowpack, and meteorological data-collection sites for evaluation of hydrologic response to climate variation.

- Establish basins for process-based studies and for estimates of future hydrologic conditions.

Although sea-level rise is an important climate-changerelated issue, it is not directly addressed by this proposed climate-response network, which focuses on inland hydrologic response. Much of the "Climate and Hydrology of New England" section of this report is updated text from Hodgkins and others (2009).

\section{Climate and Hydrology of New England}

The climate of New England is complex and variable; latitude, proximity to the Atlantic coast, and variations in landsurface elevation exert determinative effects on the climate (New England Regional Assessment Group, 2001). New England is about halfway between the equator and the North Pole and is affected by warm, moist air from the south and cold, dry air from the north. The Atlantic Ocean moderates air temperatures in both winter and summer. In winter, the ocean variably affects the location of snow/rain boundaries. Despite the substantial effect of the ocean, the prevailing air flow is not from the Atlantic Ocean but from the drier North American continent. The mountainous topography of northern and western New England affects precipitation and air temperatures. 
Precipitation is higher on the windward side of mountains than on the leeward side; however, because storm-track directions through the mountains are highly variable, the windward and leeward areas differ for different storms. Air temperature generally decreases with increasing elevation.

Streamflows in New England typically are highest in the spring, when rain falls on a ripe snowpack or on saturated soils. Streamflows recede as snowmelt ends and as evapotranspiration increases. This recession is frequently interrupted by runoff from rainstorms. Warm-season streamflows are usually lowest in August and September. In the fall, after evapotranspiration decreases substantially, repeated rains often saturate the soil and lead to high streamflows. Also in the fall, large amounts of rain can fall as a result of hurricanes, tropical storms, or their remnants. Winter streamflows are generally low in northern New England, where winter precipitation typically falls as snow. Winter streamflows in southern New England can be more variable than streamflows in northern New England because of more winter rain.

The snowpack in New England typically accumulates throughout the winter and reaches its maximum depth and water equivalent (the amount of water stored in the snowpack) in northern New England (where the snowpack is more substantial than in southern New England) in March or April. The median seasonal maximum depth of the snowpack from 1955 to 1992 varied from less than 8 inches (in.) in coastal Connecticut and Rhode Island to more than 32 in. in the mountains of western Maine and northern New Hampshire and in northern Maine (Cember and Wilks, 1993). Most historical field-based data for snow water equivalent in New England have been collected in Maine. The average water equivalent on or near March 1 ranged from 3 to 5 in. along the Maine coast to 7 to $9 \mathrm{in}$. in the western mountains and in northern Maine (Loiselle and Hodgkins, 2002). The 109 datacollection sites analyzed by Loiselle and Hodgkins (2002) had an average of 43 years of record through 2000. Almost all of the data-collection sites were lower than 2,000 feet ( $\mathrm{ft}$ ) in elevation and therefore do not represent the full range of average water equivalent in Maine, as many mountains have elevations higher than $2,000 \mathrm{ft}$.

\section{Historical Climate and Hydrologic Changes in New England}

Climate-related seasonal hydrologic changes have been documented in New England on the basis of data collected during the last 50 to 200 years. Many changes have been documented in winter and spring, whereas some changes have been found in summer and fall and for annual flow variables. Overall, there is strong regionally coherent evidence of changes consistent with increasing air temperatures in late winter and spring in the last 30 to 40 years in northern New England (Maine, New Hampshire, and Vermont).

\section{Annual}

Various changes in low to high annual streamflows in New England have been documented (Hodgkins and Dudley, 2005). Annual low streamflows significantly increased $(p<0.1)$ at several streamflow-gaging stations in northern New England from the early to mid-1900s through 2002. Annual peak flows have increased significantly during the last 50 to 100 years at several streamflow-gaging stations across New England (Hodgkins and Dudley, 2005; Collins, 2009; Hodgkins, 2010a; Armstrong and others, 2012).

Annual maximum and minimum groundwater levels during the most recent 20 and 30 years have increased in northern New England (Dudley and Hodgkins, 2013); in general, increases in maximum levels have been greater than increases in minimum levels, resulting in trends toward an increasing annual range. Weider and Boutt (2010) found groundwater levels increasing overall in New England in the last decade. Precipitation has increased in New England across all seasons (Karl and Knight, 1998; Douglas and Fairbanks, 2011; Hodgkins and Dudley, 2011).

Sea level has been rising globally for the past 20,000 years largely because of melting continental ice sheets that accumulated during the last ice age (Poore and others, 2000). One of the projected effects of climate warming is a continued rise in sea level caused by a combination of melting glaciers and ice sheets (on land) and thermal expansion of the ocean, called eustatic sea-level rise (Frumhoff and others, 2007). Historical rates of relative sea-level rise (eustatic sea-level rise combined with the effects of land subsidence) measured along the coast of New England during the last century (48 to 101 years of data through 2013) range from 0.07 to 0.14 inches per year (in/yr; National Oceanic and Atmospheric Administration, 2014). Future estimated rates of eustatic sea-level rise range from 0.05 to $0.33 \mathrm{in} / \mathrm{yr}$ (Kirshen and others, 2008). The USGS, in cooperation with the National Park Service, recently conducted a study to estimate future inundation of salt marshes in response to sea-level rise in Acadia National Park, Maine, and the surrounding region (Nielsen and Dudley, 2013).

\section{Winter and Spring}

March mean streamflows increased significantly over time $(p<0.1)$ at 14 of 27 streamflow-gaging stations in New England; all of the significant increases were in northern New England. Flows increased 76 to 185 percent at the seven stations with the longest continuous records (1920s or 1930s through 2002) in northern New England (Hodgkins and Dudley, 2005). There were no stations with significant decreases. The streamflow changes in northern New England are likely related to changes in snowpack melt, though changes in precipitation patterns and other factors could also contribute to the changes in streamflow (Hodgkins and Dudley, 2006b). Increased air temperatures cause increased late-winter flows through earlier snowmelt and more 
precipitation falling as rain. Eighteen of 23 snow-measurement sites in northern New England with at least 50 years of records had a significant decrease $(p<0.1)$ in late-winter snowpack depth or an increase in snowpack density (Hodgkins and Dudley, 2006a). Increased snowpack density over time for a set late-winter date indicates that the snow has become more ready to melt by that date.

The ratio of December through March snowfall to total precipitation decreased significantly $(p=0.043)$ for the average of four U.S. Historical Climatology Network (USHCN) stations in northern New England from 1949 to 2000. The year-to-year ratio of snowfall to total precipitation in northern New England was correlated with air temperature $(r=-0.45$, $p=0.008)$ and total snowfall $(r=0.48, p=0.0003)$ but not with total precipitation $(r=-0.078, p=0.59$; Huntington and others, 2004). This supports the idea that winter snow and runoff in New England have been more sensitive to air temperature changes than to changes in precipitation amount.

Huntington and others (2003) found a significant decrease over time $(p=0.0021)$ in average ice thickness around February 28 on the Piscataquis River in central Maine. The ice thinned about 9 in. (45 percent) from 1912 to 2001.
On average, for the nine rivers in northern New England with the longest records, river-ice occurrence (total number of winter days with ice-affected flow) decreased significantly ( $p=0.0013$ ) from 1936 to 2000 (Hodgkins, Dudley, and Huntington, 2005a). Most of the 20-day change in the total days of ice occurred from the 1960s to 2000. Year-to-year river-ice occurrence was highly correlated with winter air temperature $(r=-0.70, p<0.0001)$ and less highly correlated with winter precipitation $(r=-0.52, p<0.0001)$. More days of river ice were associated with colder temperatures and lower precipitation (Hodgkins, Dudley, and Huntington, 2005a).

Winter-spring streamflows became earlier at many rivers in New England during the 20th century; significant trends were mostly in northern New England. Most of the 1- to 2-week change in northern New England occurred in the most recent three decades through 2002 (Dudley and Hodgkins, 2002; Hodgkins and others, 2003; Hodgkins and Dudley, 2006b). Winter-spring streamflow timing is based on the center-of-volume date - the date, each year, on which half of the winter-spring streamflow volume passes a streamflowgaging station. Historical winter-spring streamflow timing for the Piscataquis River in central Maine is shown in figure 1.

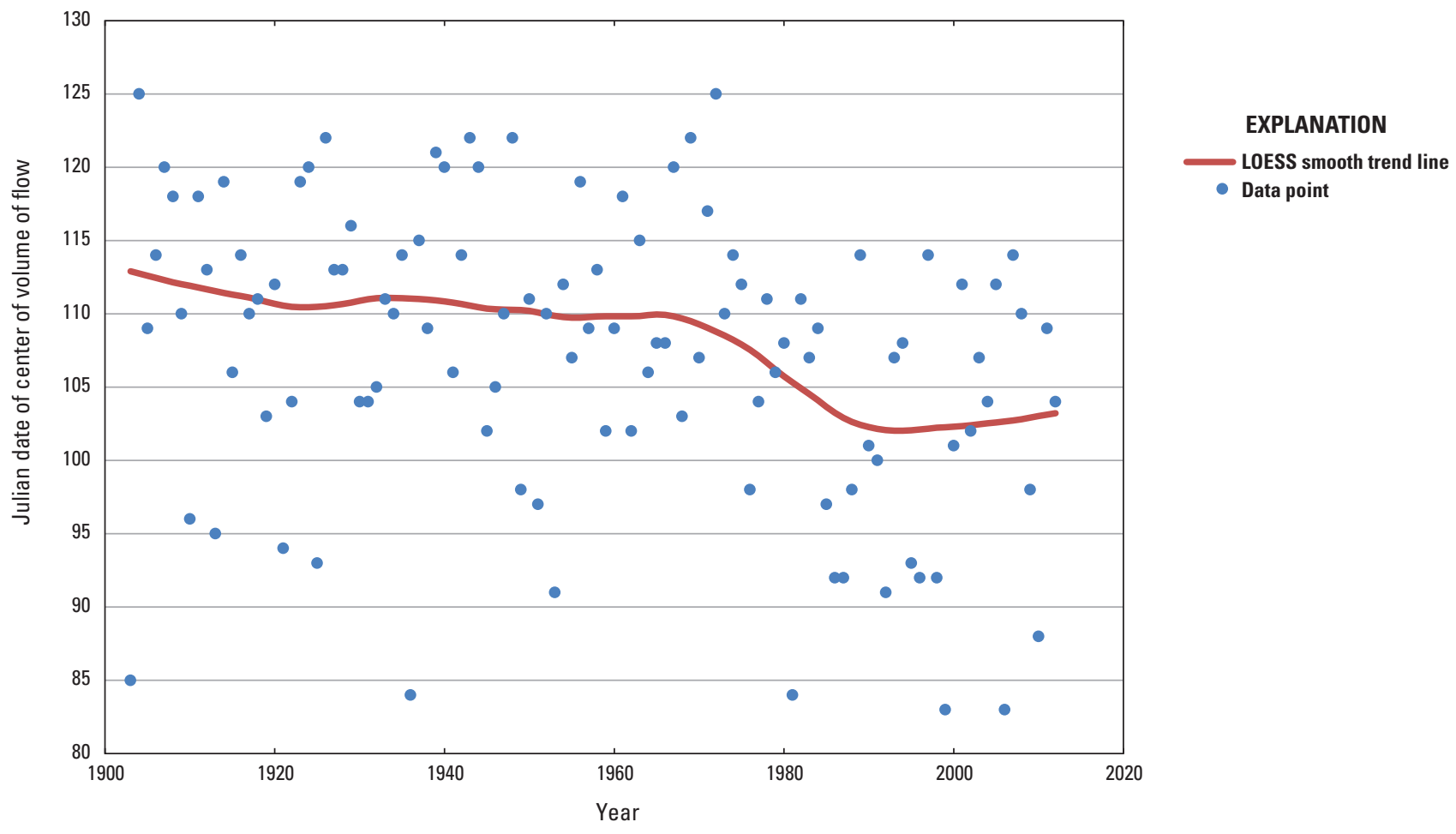

Figure 1. Historical winter-spring streamflow timing for the Piscataquis River in central Maine. The Julian date in is the sequential number of days in a year, with January 1 being day 1 . (Julian date 90, for example, corresponds to March 31 in a nonleap year.) A local regression (LOESS) smoothing line is shown in red. 
Framework for a Hydrologic Climate-Response Network in New England

Year-to-year streamflow timing was highly correlated with March-through-April air temperature $(r=-0.72, p<0.0001$; Hodgkins and others, 2003). Higher air temperatures were associated with earlier streamflows. The highest correlation coefficient between streamflow timing and precipitation was $-0.37(p=0.0018)$ with January precipitation. May streamflows decreased significantly $(p<0.1)$ at 10 of 27 stations in New England; all of these decreases were in northern New England. Flows decreased 9 to 46 percent at the seven stations with the longest continuous records (Hodgkins and Dudley, 2005). No stations showed significant increases. Higher winter (December through March) precipitation is associated with higher April streamflows at many streamflow-gaging stations in northern and central New England (Hodgkins and others, 2012). This indicates that snowpack accumulation is an important mechanism for winter water storage and subsequently important for spring streamflows in this area. Higher March air temperatures are associated with lower April streamflows at many streamflow-gaging stations in central and southern New England, likely because the majority of snowmelt runoff occurs before April in warm years.

Dudley and Hodgkins (2013) documented increases in monthly groundwater levels in northern New England during the winter and spring during the past 30 years. The highest annual groundwater levels most commonly occur during spring or early summer (March through June), most frequently in April. April month-end levels correlate strongly with April mean streamflow and winter-spring runoff volume. While winter-spring streamflow timing in the Northeast has become earlier during the past century, this timing has not been observed to correlate with April groundwater levels or any other monthly groundwater levels (Dudley and Hodgkins, 2013).

On average, for the nine rivers in northern New England with the longest records, river-ice breakup dates (the annual last spring days of ice-affected flow) became significantly earlier ( $p=0.0037$ ) from 1936 to 2000. No appropriate riverice data were available in southern New England. Most of the 11-day change in river-ice breakup in northern New England occurred from the 1960s to 2000 (Hodgkins, Dudley, and Huntington, 2005a). River-ice breakup was highly correlated with March-through-April air temperature $(r=-0.73$, $p<0.0001)$ and less highly correlated with precipitation (highest $r=-0.37, p=0.0027$; Hodgkins, Dudley, and Huntington, 2005a).

Lake ice-out dates became significantly earlier at all five lakes in New England that had data from the mid-1800s to the early 2000s (Hodgkins and others, 2002; Benson and others, 2012; Hodgkins, 2013). Ice-out dates between 1859 and 2008 at representative lakes (Hodgkins and others, 2002), were 8.4 days earlier in northern/mountainous areas of northern New England and 13.5 days earlier in more southern areas of northern New England (Hodgkins, 2013). No long-term ice-out data are known from lakes in rural areas of southern New England. Historical ice-out dates for Damariscotta Lake in midcoastal Maine are shown in figure 2. The magnitude of trends over time depends on the length of the historical period considered. Lake ice-out dates during the last 50 years became earlier by 1.8 days per decade, based on the median change for all lakes with adequate data. This rate of change is much higher than those observed over longer historical periods; ice-outs became earlier by 0.6 days per decade during the last 75 years, 0.4 days per decade during the last 100 years, and 0.6 days per decade during the last 125 years (Hodgkins, 2013).

\section{Summer and Fall}

There is evidence of historical summer and fall hydrologic changes in New England. In summer, the lowest base flows increased from 1950 to 2006 at most streamflowgaging stations in western New England (Hodgkins and Dudley, 2011). Many increases were greater than 20 percent, and some increases were greater than 50 percent in and near New Hampshire and Vermont. In contrast, some decreases were greater than 20 percent in the lowest base flows in northern and coastal areas of Maine. Summer air temperature in New England increased on average by 2.0 degrees Fahrenheit $\left({ }^{\circ} \mathrm{F}\right)$ from 1950 to 2006 and may have played a role in the decreased base flows for streams in northern and coastal Maine by increasing evapotranspiration in areas with substantial wetlands and open-water bodies. Small decreases in precipitation in parts of this area may also have contributed to the base-flow decreases (Hodgkins and Dudley, 2011).

The timing and magnitude of low flows (which typically occur in the late summer and early fall in New England) are much more highly correlated with summer precipitation than with air temperature (Hodgkins, Dudley, and Huntington, 2005b). No strong relation was found between historical April streamflows and late-spring or summer streamflows in New England (Hodgkins and others, 2012). The lack of a strong relation implies that summer precipitation, rather than spring conditions, controls summer streamflows.

Dudley and Hodgkins (2013) documented increases in monthly groundwater levels in northern New England during the summer and fall during the past 30 years. The lowest groundwater levels most commonly occur during summer or fall (July through November), most frequently in September. September levels correlate strongly with August groundwater levels and August and September streamflows as well as with September base flow. Base flow from groundwater discharge typically supplies a large portion of streamflow during July, August, and September because of the relatively low amount of surface-water runoff in these months.

Summer stormflows increased from 1950 to 2006 by more than 50 percent at many stations in New England, particularly in and near New Hampshire and Vermont. Summer rainfall increased at most weather stations in New England from 1950 to 2006, with many increases of more than 20 percent in western New England (Hodgkins and Dudley, 2011). 


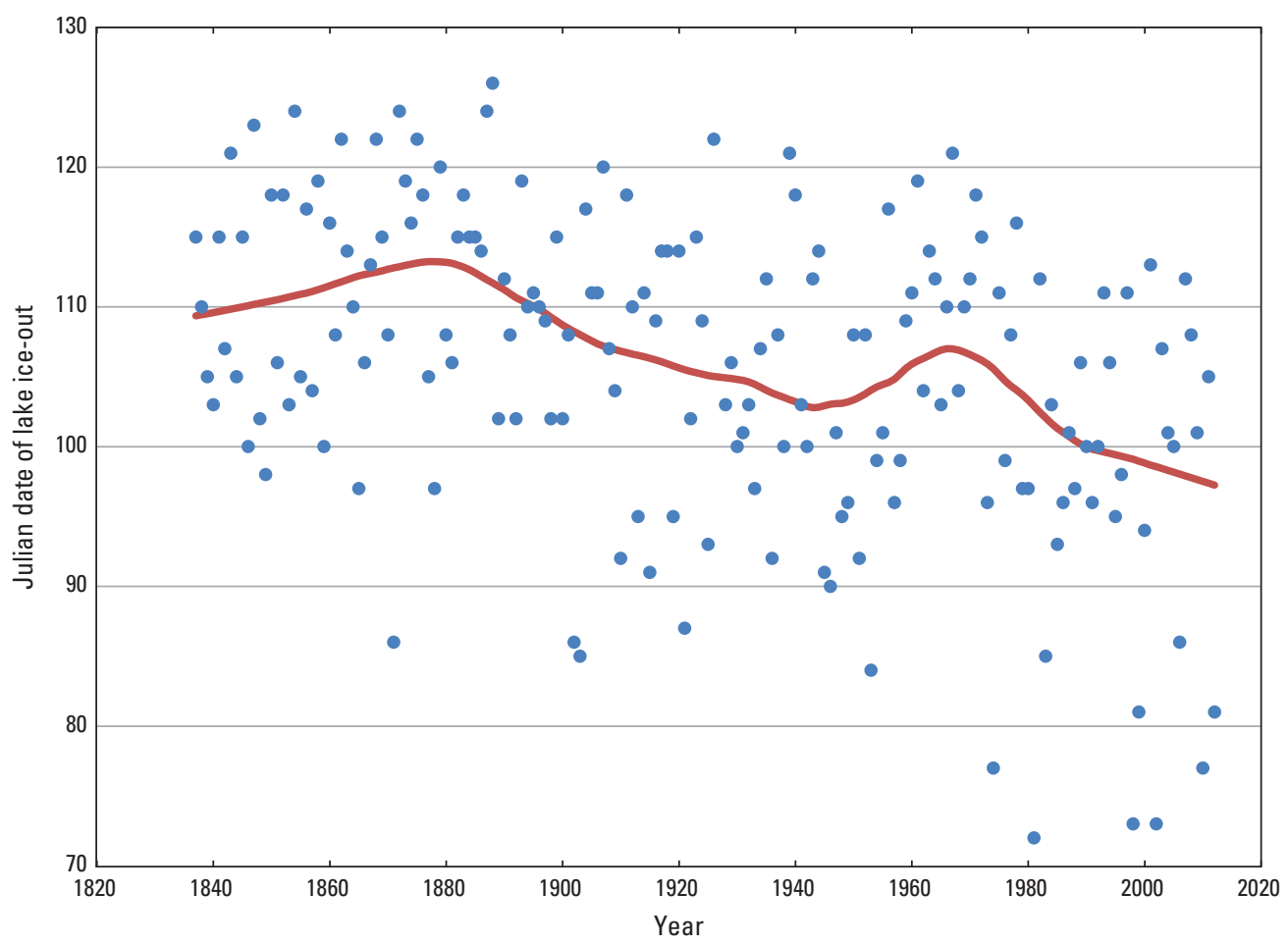

EXPLANATION

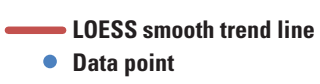

Figure 2. Historical ice-out dates for Damariscotta Lake in midcoastal Maine. The Julian date in is the sequential number of days in a year, with January 1 being day 1. A local regression (LOESS) smoothing line is shown in red.

Some consistent hydrologic changes during the fall in New England have been observed. Four of 16 rivers in northern New England had significantly later $(p<0.1)$ first fall days of river ice from the first half of the twentieth century to 2000; no rivers had significantly earlier first fall days of ice (Hodgkins, Dudley, and Huntington, 2005a). Some significant changes in the timing or magnitude of fall high flows have been found (Hodgkins and others, 2003; Dudley and Hodgkins, 2005; Hodgkins and Dudley, 2005). October streamflows significantly increased at five rivers in western New England through 2002; no rivers had significant decreases (Hodgkins and Dudley, 2005).

\section{Drivers of Climate-Response Network Hydrologic Variables}

Precipitation and (or) temperature variability typically drive the variability of hydrologic response. These meteorological drivers can differ by season. Organizing New England hydrologic climate-response variables by their important drivers increases understanding of which parts of the hydrologic cycle are expected to be affected by future temperature or precipitation change and whether the changes are expected to be caused by annual or seasonal changes (table 1).

Table 1. Annual and seasonal climatic drivers of hydrologic variability in New England.

[--, no variables included]

\begin{tabular}{cccc}
\hline \multirow{2}{*}{ Climatic driver } & \multicolumn{3}{c}{ Anndrologic climate-response variables } \\
\cline { 2 - 3 } Temperature & Annual peak flow & $\begin{array}{c}\text { Winter and spring } \\
\text { Winter-spring runoff timing } \\
\text { Lake ice-out dates }\end{array}$ & Summer and fall \\
Precipitation & Annual peak flow & -- & - \\
& & $\begin{array}{l}\text { Groundwater levels } \\
\text { Base-flow magnitude }\end{array}$ \\
\hline
\end{tabular}


Framework for a Hydrologic Climate-Response Network in New England

\section{Future Hydrologic Changes in New England}

Output from recent modeling using multiple atmosphereocean general circulation models (GCMs) provides a range of climate projections for the northeastern United States. The GCMs were regionally downscaled and were forced with the low (B1), mid-high (A2), and high (A1FI) greenhouse-gas emission scenarios as described by Nakićenović and others (2000). Hayhoe and others (2007) used climate projections as input to the variable infiltration capacity (VIC) hydrologic model to simulate future hydrologic responses. Spring streamflow timing is expected to become earlier by 5 to 8 days, and annual 7-day low flows are expected to decrease by 1 to 4 percent between the periods 1961-90 and 2035-64 (Hayhoe and others, 2007). Projected low-flow changes by midcentury are small under the low- and mid-high-emissions scenarios; however, under the high-emissions scenario, larger decreases (11 percent) are projected by the period 2070-99. The number of short-term and long-term droughts (based on soil moisture deficits) is expected to increase by the period 2035-64. Total annual snow-water equivalent and the number of days with snow per month are expected to decrease. The central tendencies of general circulation model output indicate modest increases (about 10 percent) for New England annual precipitation and air temperature increases from about 1.8 to $5.4^{\circ} \mathrm{F}$ ( 1 to 3 degrees Celsius $\left[{ }^{\circ} \mathrm{C}\right]$ ) by the end of the century (Markstrom and others, 2012).

Cathance Stream Basin in Maine (Mastin and others, 2011; Dudley and others, 2012) and Pomperaug River Basin in Connecticut (Bjerklie and others, 2012) were 2 of 14 distributed-parameter Precipitation-Runoff Modeling System (PRMS) existing watershed models in the United States used to determine the sensitivity and potential effects of long-term climate change on freshwater resources across the United States (Markstrom and others, 2012). Regionally downscaled output from five GCMs and low (B1), medium (A1B), and mid-high (A2) greenhouse-gas emissions scenarios were used to estimate an ensemble of climate-change input scenarios for the basins. Projected increases in maximum and minimum daily air temperatures for all climate change scenarios for the 21 st century result in projected decreases in the percentage of precipitation that falls as snow, snowpack water equivalent, and snowmelt. The projected changes in snowpack accumulation and melt would affect the seasonal amount and timing of streamflow. PRMS-modeled flows indicate that the projected changes in snowmelt timing will result in increases in streamflow for winter to early spring months (January through March) and decreases for spring months (April through June). The Cathance model indicates warmer winters will result in increased groundwater recharge during winter months (Pomperaug indicates future increases only for January) and decreases in recharge for all other times of the year. The Cathance and Pomperaug models indicate overall modest increases (about 10 percent) in precipitation over time, longer growing seasons, increases in evapotranspiration, and decreases in soil moisture (Markstrom and others, 2012).
Bjerklie and others (2011) estimated future changes in snowfall and groundwater recharge by using a regional watershed model for watersheds contributing to Long Island Sound, mostly from New England, including the Connecticut River Basin. GCM forecasted climate conditions were based on the B1 and A2 scenarios. Watershed model output for both scenarios for the end of the 21st century indicated increases in groundwater recharge over much of the region and substantial snowfall decreases across Massachusetts, Connecticut, southern Vermont, and southern New Hampshire relative to the beginning of the 21 st century.

The USGS, in cooperation with the Maine Department of Transportation, studied changes in peak flows at four basins in coastal Maine on the basis of projected changes in air temperature and precipitation (Hodgkins and Dudley, 2013). The study used PRMS models to estimate future peak flows by way of a sensitivity analysis; a matrix of combinations that bracket probable future changes in precipitation and air temperature were applied to the historical meteorological input data for the models, and peak flows of specified annual exceedance probabilities (design flows) were computed from the PRMS model output for each basin. Air temperatures were adjusted by four different amounts, from $-3.6^{\circ} \mathrm{F}\left(-2{ }^{\circ} \mathrm{C}\right)$ to $10.8^{\circ} \mathrm{F}\left(6^{\circ} \mathrm{C}\right)$ of observed temperatures. Precipitation was adjusted by three different percentage values, from -15 percent to 30 percent of observed precipitation.

The study results indicated that increases in air temperature (with no changes in precipitation) lead to decreases in peak flows, a likely result of decreases in winter snowpack accumulation and thus decreases in snowmelt runoff. Increases in precipitation (with no changes in temperature) lead to increases in peak flows. For likely changes projected for the northeastern United States for the middle of the 21 st century (combined temperature increase of $3.6^{\circ} \mathrm{F}$ and precipitation increases of 0 to 15 percent), peak-flow changes at the four coastal Maine basins in this study were modeled to be evenly distributed between increases and decreases of less than 25 percent (Hodgkins and Dudley, 2013). Peak-flow increases caused by precipitation increases are largely balanced by peakflow decreases caused by air temperature increases.

\section{Potential Effects of Hydrologic Changes}

Effects of climate change on hydrology could affect human water supply, hydroelectric power generation, transportation infrastructure, and stream and riparian ecology in the northeastern United States. Earlier snowmelt runoff could affect sensitive water systems by reducing water availability in the summer. Managers of storage reservoirs may need to modify operation schedules or increase reservoir storage earlier in the spring to allow for successful operation in a potentially longer summer low-flow season.

Changes in streamflow in the northeastern United States could also be important for other reasons; for example, increased winter flows can and have caused an increase in the 
frequency of midwinter ice jams (Beltaos, 2002). River ice jams can cause major flooding and damage river infrastructure. Ice jams played a major role in New England flooding in 1936 and 1991 (Grover, 1937; Wuebben and others, 1995).

Changes in the timing or magnitude of future streamflows will likely affect ecosystems. The ecological implications of changes in winter-spring streamflow timing in New England are not well understood. One possible effect is a greater challenge for the survival of Atlantic salmon. If the peak spring migration of juvenile salmon from freshwater rivers (which is controlled by photoperiod, temperature, and flow) becomes out of phase with optimal environmental conditions in rivers, estuaries, or the ocean, this could present a greater challenge to salmon survivability (McCormick and others, 1998). Changes in the timing of high spring flow and recession to summer low flows may be related to the observed altered timing of migration of Atlantic salmon (Huntington and others, 2003; Juanes and others, 2004).

Trends toward earlier snowmelt and increased summer evapotranspiration rates could shorten the annual periods of standing water used by amphibians for breeding in forested depressional wetlands (vernal pools; Brooks, 2009). Increases in summer evapotranspiration could decrease river base flows, which include surface water released naturally from storage in lakes, ponds, and wetlands (Hodgkins and Dudley, 2011). Lowered base flows could reduce available fish habitat during low-flow periods.

River ice causes many erosional and depositional features in river channels and on channel floodplains, especially in northern New England. Physical disturbances associated with ice-breakup scouring and flooding are important to nutrient and organic-matter dynamics, water chemistry, and the abundance and diversity of river biota (Prowse and Beltaos, 2002). The succession of riparian vegetation is directly linked to the scouring effects of ice (Prowse and Beltaos, 2002). River-ice breakup is likely to have important effects on primary producers, consumers, and food-web dynamics of river biota, although detailed information describing the magnitude of their effects is scarce (Scrimgeour and others, 1994). Mortality, emigration, or displacement of fishes at all life stages often results from severe ice conditions, through the actions of damming, scouring, associated flooding, or direct freezing (Power and others, 1993). Anchor ice, slush ice that adheres to streambeds, can have serious effects on fish eggs and embryos developing within gravel beds (Prowse, 1994). Anchor ice does not form when surface-ice cover is present, and therefore anchor ice could increase as surface-ice cover decreases.

Earlier lake ice-out dates are correlated with lower late-summer hypolimnion lake oxygen levels on the basis of limited data from northern New England (Hodgkins, 2013). Climatic warming has been shown in modeling studies to cause earlier lake ice-out dates, longer periods of summer stratification, and lower summer lake oxygen levels (Stefan and others, 1993; Elo and others, 1998). The lowering of hypolimnion oxygen levels could lead to enhancement of phosphorus release from sediments and increased lake eutrophication (Elo and others, 1998; Nõges and others, 2009). Trends toward earlier ice-outs and thus increased light availability, lake circulation, and water temperatures could lead to changes in spring and summer phytoplankton and zooplankton dynamics and benthic invertebrate abundance (Jassby and others, 1990; Porter and others, 1996; Blenckner, Omstedt, and Rummukainen, 2002; Blenckner, Pettersson, and Padisák, 2002).

In summary, historical climate-related seasonal hydrologic changes have been documented in New England in recent decades. Winter-spring hydrologic changes are related more to changes in air temperatures than to changes in precipitation; in contrast, summer-fall hydrologic changes are related more to changes in precipitation. Annual peak flows are affected by changes in both air temperature and precipitation. Future climatic changes will likely affect human infrastructure and stream ecology in New England.

\section{Framework for a Hydrologic Climate- Response Network}

The framework of a hydrologic climate-response network for New England has four major purposes:

- Identify specific hydrologic variables that are sensitive to climate change. This has been done in the "Climate and Hydrology of New England" section.

- Identify climate-response regions: geographic regions grouped by similar hydrologic responses.

- Propose a fixed-station monitoring network composed of existing streamflow, groundwater, lake ice, snowpack, and meteorological data-collection sites for evaluation of inland hydrologic response to climate variation.

- Establish basins for process-based studies and for estimates of future hydrologic conditions.

\section{Climate-Response Regions}

Hydrologic climate-response regions should have relatively homogeneous climates. New England's climate, as described in the "Climate and Hydrology of New England" section, is complex, with large north-to-south, coastal-toinland, and sea-level-to-mountain-region gradients. New England would be divided into 14 regions (fig. 3, table 2) that follow major river-basin boundaries, have relatively homogeneous climates, and contain data-network sites with similar values or trends in key hydrologic variables. The 14 lower tier regions would be grouped into 4 upper tier regions according to similarities that are most evident at a coarse geographic scale. The upper tier regions would each be identified by a four-digit sequence, and the lower tier regions 


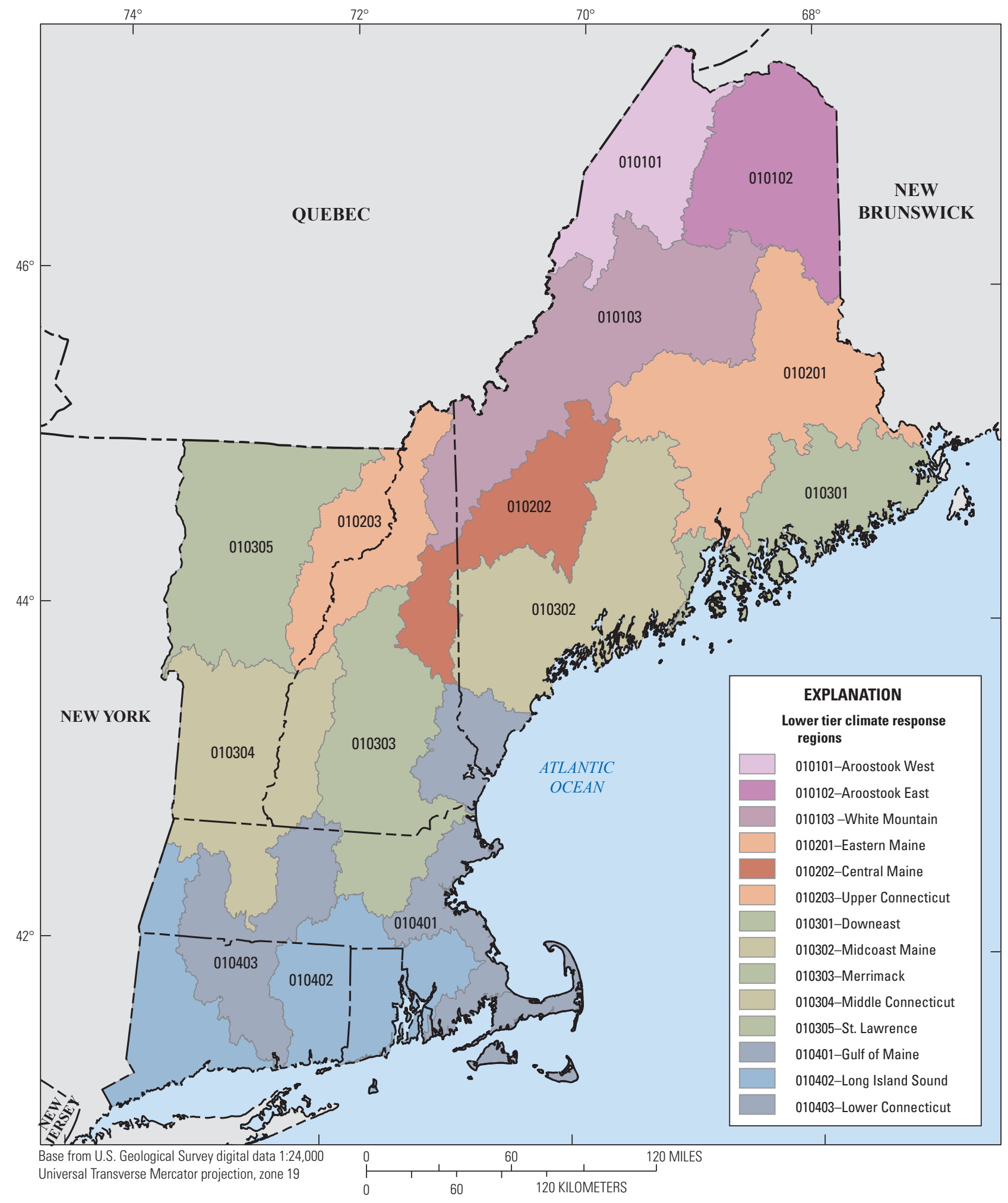

Figure 3. Hydrologic climate-response regions in New England. 
Table 2. Description of hydrologic climate-response regions in New England.

[See figure 3 for climate-response region locations. CRR, climate-response region; St., Saint; NH, New Hampshire]

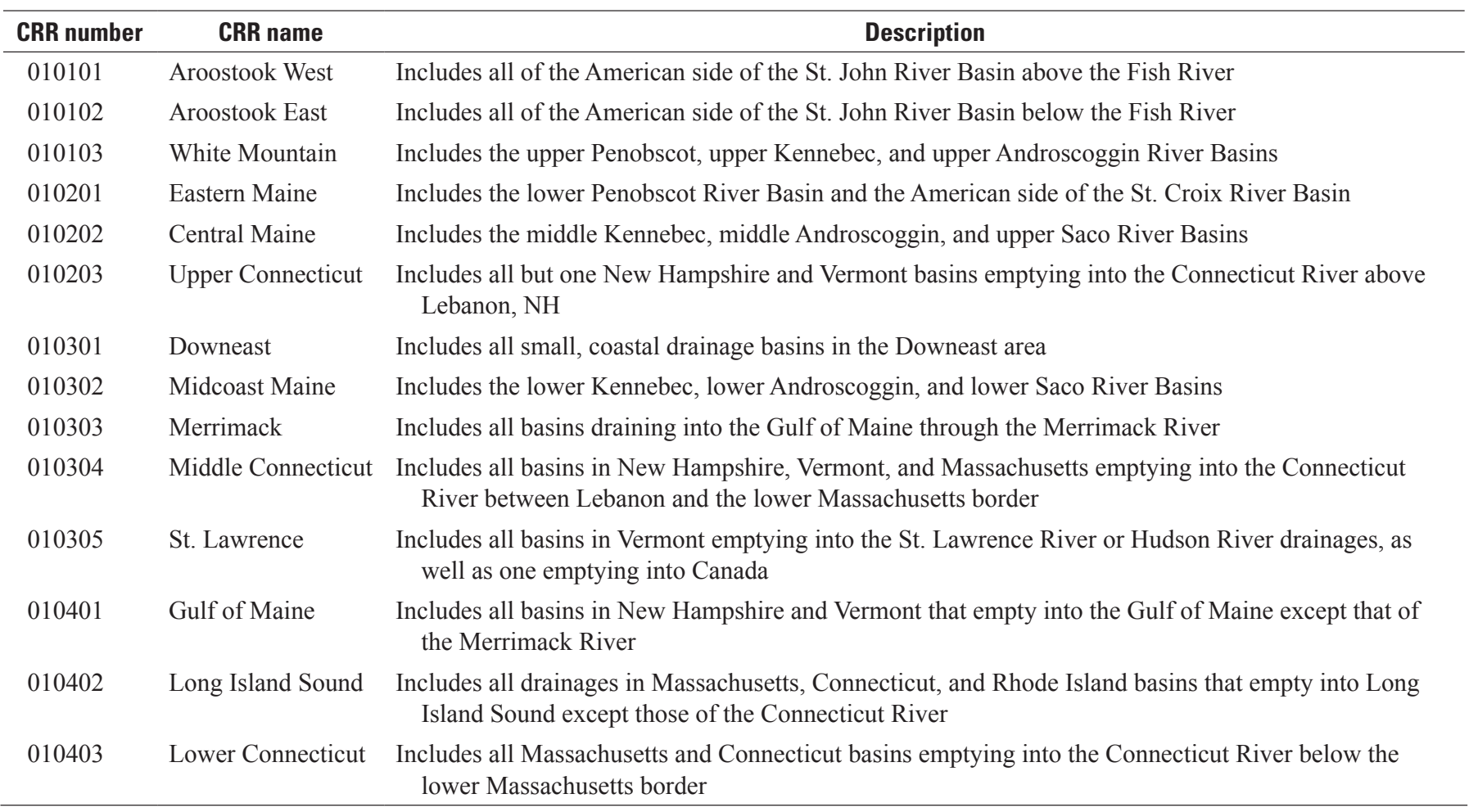

would be designated by the four-digit identifier of their parent higher tier region, followed by a two-digit suffix. Smoothed plots of winter-spring streamflow timing (fig. 4) and historical lake ice-out dates (fig. 5) in New England show that individual lakes and streams, for these variables, generally group well by upper tier climate-response region, particularly for winterspring streamflow timing.

Major river-basin boundaries were followed for hydrologic climate-response-region boundaries. The current proposed configuration of the climate-response regions is optimized to best fit the spatial patterns in key hydrologic variables that have already been identified, but results of additional analyses of hydrologic variations could inform changes to the boundaries and (or) number of hydrologic climateresponse regions in the future.

\section{Primary Components and Associated Key Variables of a Hydrologic Climate-Response Network}

Establishing a hydrologic climate-response network includes the identification of hydrologic components that include the major fluxes (such as streamflow) and storage compartments (such as groundwater storage) of the regional water cycle. Each component has one or more key variables that can be feasibly measured at data-collection sites. For example, streamflow has been identified as a component, with a key variable of streamflow being winter-spring streamflow timing. The key variables of components discussed in this section have been demonstrated to be responsive to climate change or are expected to be responsive to it in the next few decades, and are important for human water use or ecosystem function.

Three criteria were used to identify key variables to be included in a hydrologic climate-response data network: the existence of long-term historical data, the expectation that a variable will be responsive to changes in precipitation and (or) air temperature during the next few decades, and the human or ecological importance of the component variables. Long-term historical data allow a more complete perspective on future climate-related changes than short-term data because past decadal variability and longer term changes are better known. The "Climate and Hydrology of New England" section of this report lists known historical changes for variables of several hydrologic components and the known importance of these variables for humans and ecosystems. Many variables can be used to describe some of the components in a hydrologic climate-response data network. For example, streamflow variables could include annual peak flows, March mean flows, or many other measures. On the basis of extensive past work, some variables are more likely than others to be responsive to 


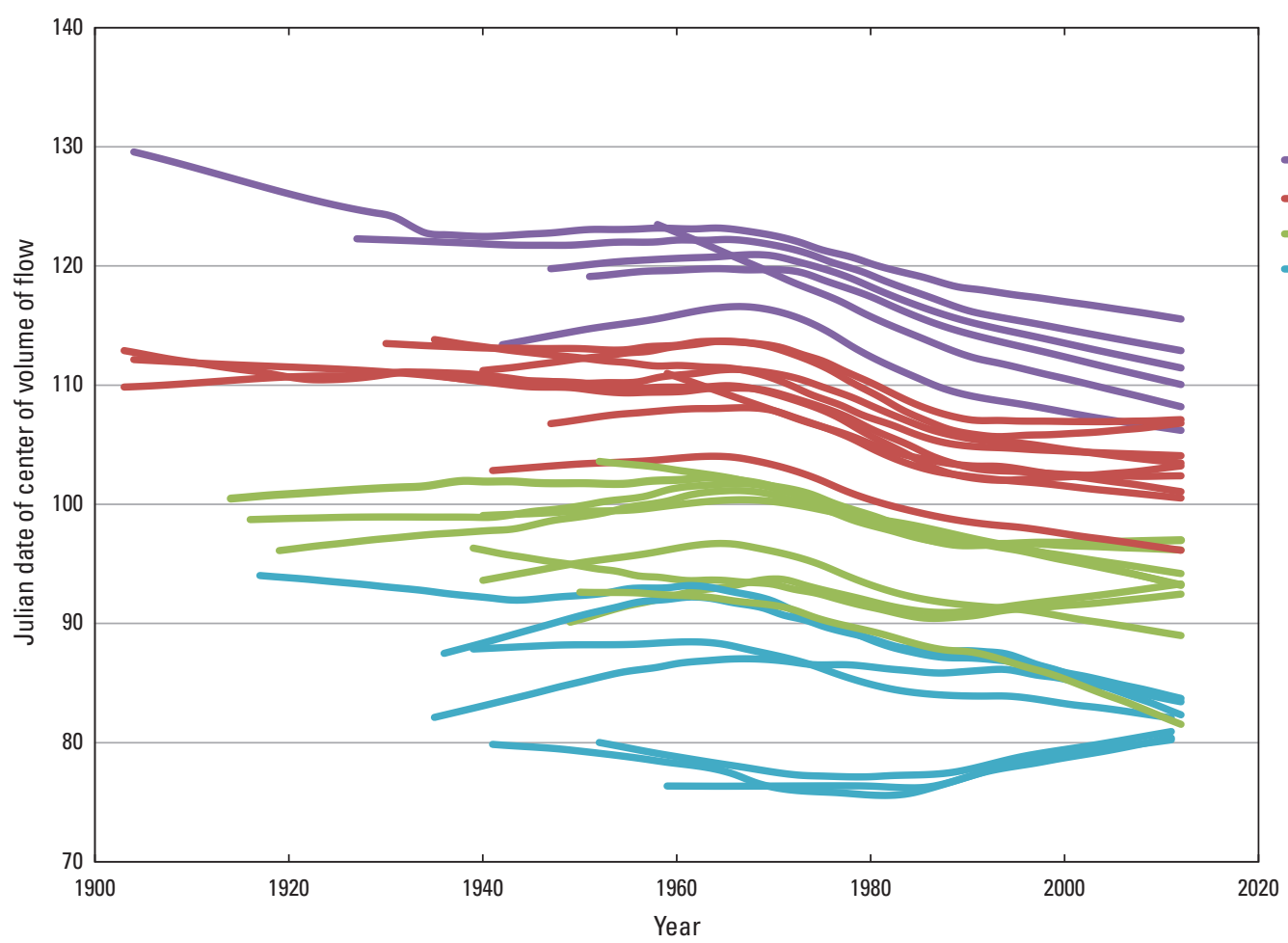

\section{EXPLANATION}

Upper tier climate response region 0101

Upper tier climate response region 0102

Upper tier climate response region 0103

Upper tier climate response region 0104

Figure 4. Winter-spring streamflow timing for streams in New England.

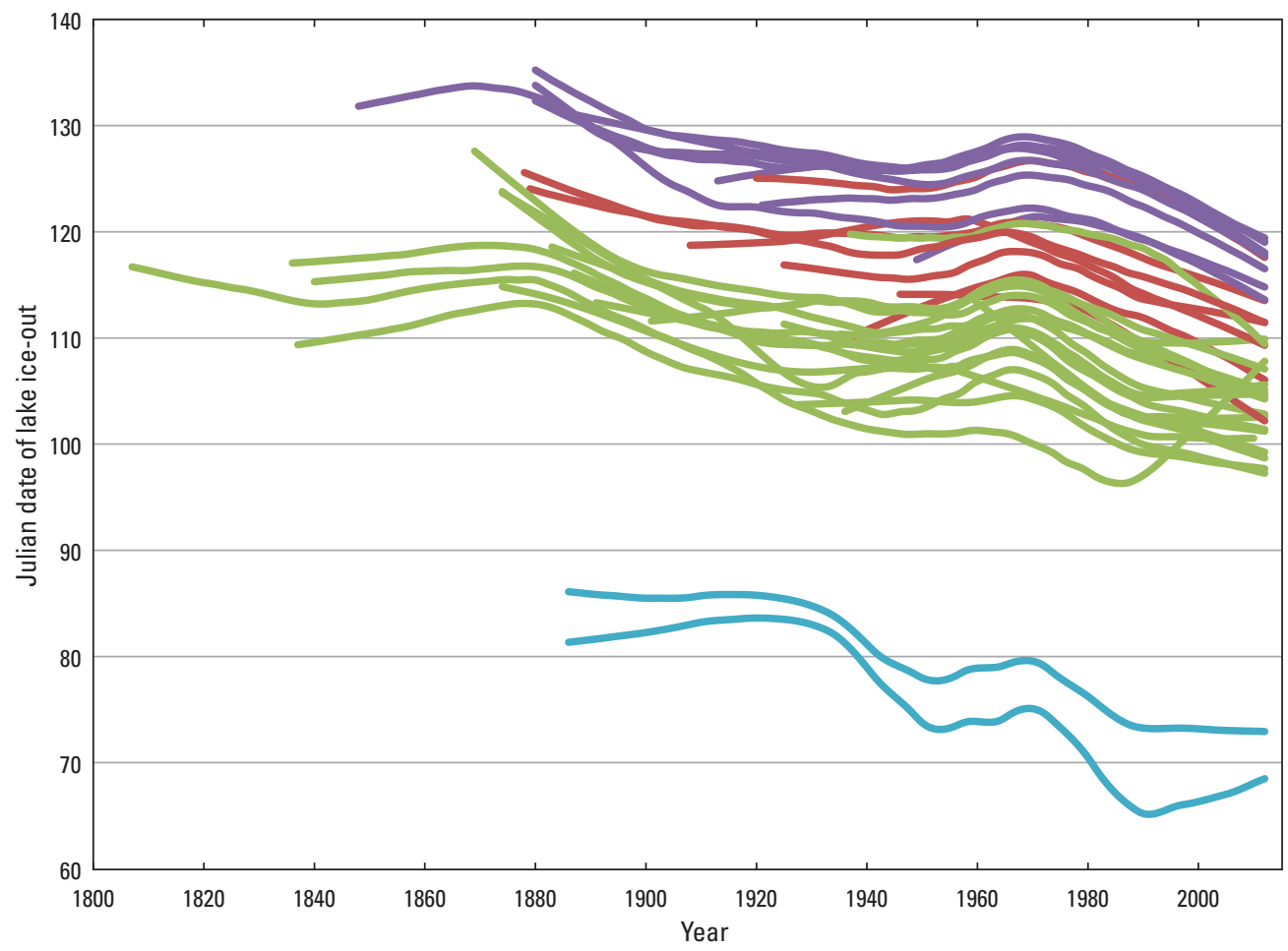

EXPLANATION

Upper tier climate response region 0101 Upper tier climate response region 0102 Upper tier climate response region 0103 Upper tier climate response region 0104

Figure 5. Historical lake ice-out dates in New England. 
changes in precipitation and (or) air temperature (see "Climate and Hydrology of New England" section). Components proposed for inclusion in a hydrologic climate-response data network have at least one key variable with extensive historical data at multiple sites: streamflow, groundwater, lake ice, snowpack, and meteorological data. Other hydrologic components, such as water quality, are important to humans and (or) ecosystems but lack variables with extensive historical data. Key variables of primary components are listed in the following sections; additional components and (or) variables could be added as part of a larger network.

\section{Streamflow}

For the streamflow component, two key variables are proposed: winter-spring streamflow timing and the magnitude of the annual peak flow. Winter-spring streamflow timing is measured by the winter-spring center-of-volume (WSCV) date (Dudley and Hodgkins, 2002; Hodgkins and others, 2003; Hodgkins and Dudley, 2006b). The WSCV is a robust measure of streamflow timing. To compute the WSCV date, daily flow volumes from the start to the end of the annual winter-spring season are summed. The WSCV date is the date, in counting from the start of the season, by which half of the volume flows by a streamflow-gaging station. Another key variable derived from streamflow data - the magnitude of summer base flows - is discussed in the "Groundwater" section.

The USGS has been measuring and recording daily streamflow at some sites in New England for more than a century. More than 50 years of streamflow data are available for many rural, unregulated streams through the USGS National Water Information System (http://waterdata.usgs.gov/ usa/nwis/sw). The streamflow data at these sites have been collected by the USGS using consistent, well-documented, high-quality methods (Corbett and others, 1943; Rantz and others, 1982). Therefore, historical changes in the data can be determined with confidence.

Streamflow data proposed for New England are from USGS streamflow-gaging stations that have streamflows which are minimally affected by direct human watershed changes such as reservoir regulation and urbanization. The streamflow-gaging stations come from the Hydro-Climatic Data Network 2009 (HCDN-2009) subset of the USGS Geospatial Attributes of Gages for Evaluating Streamflow, version II (GAGES II), dataset (Falcone, 2011; Lins, 2012). The HCDN-2009 designation in GAGES II provides a determination of watersheds for potential study of climate-related streamflow trends; these watersheds represent hydrologic conditions least disturbed by human influences (relative to other watersheds within 12 major ecoregions in the United States) and have at least 20 years of complete and continuous data through 2009.

In some cases, stations that do not meet all of the criteria used for the HCDN-2009 network were added to the New England climate-response network. Some of the HCDN-2009 criteria were related to water-quality criteria, and stations with
Canadian drainage were not included because of the lack of basin data consistent with United States data. Active stations were added if they have had no known regular alteration of natural daily mean streamflow (high and low flows) from streamflow regulation, flow diversion or augmentation, surface-water or groundwater withdrawals, or known substantial changes in basin land use such as urbanization. Some stations with short records were added if they met this criteria and filled in gaps in spatial coverage or were important for specific reasons - for example, basins that contain important resources such as Atlantic salmon habitat and (or) Native American or U.S. Department of Interior or Agriculture lands.

Active stations in New England with 80-percent data completeness for each decade from 1960 to 2012 (11 of 13 years for 2000 to 2012) would be used to examine longterm changes in streamflow variables. Thirty-one streamflowgaging stations in New England met the criteria for minimal disturbance and long-term completeness (fig. 6; table 3). Another 30 stations in New England met the criteria for minimal disturbance and have shorter or less complete records; these stations are included in the network for shortterm trend analysis (at least 30 years) and observation (less than 30 years) but are not used for long-term analysis until the criteria for long-term stations is met. It may be desirable for certain analyses to exclude nested watersheds in New England that have substantial shared watershed area. On the basis of minimally disturbed criteria, early years of data at two stations in Maine (Carrabassett River near North Anson prior to 1931 and Little Androscoggin River near South Paris prior to 1924) are not appropriate for inclusion in low-flow analyses, nor are data for a few days with unusual regulation at one station in Maine (Narraguagus River at Cherryfield in 1978 and 1985). Although the majority of the streamflow-gaging stations proposed for the network (fig. 6) are in the three northern New England states, efforts are being made by the USGS in southern New England, in partnership with cooperating agencies, to initiate or reactivate additional streamflow-gaging stations in minimally altered basins for eventual inclusion in the hydrologic climate-response network.

\section{Groundwater}

Groundwater is an important source of domestic water in northern New England, where more than 60 percent of domestic water comes from groundwater and 40 percent of the population is self-supplied by private wells (Kenny and others, 2009). Groundwater-level data have been collected by the USGS in New England for several decades; levels directly measure the availability of groundwater for human use and aquatic ecosystems. In general, the records are not as long or complete as those of streamflow. Historical groundwater records often exhibit monthly or longer sampling frequencies with fragmentary periods of record. As a consequence, it is challenging to meet record-completeness criteria necessary for long-term trend testing. 


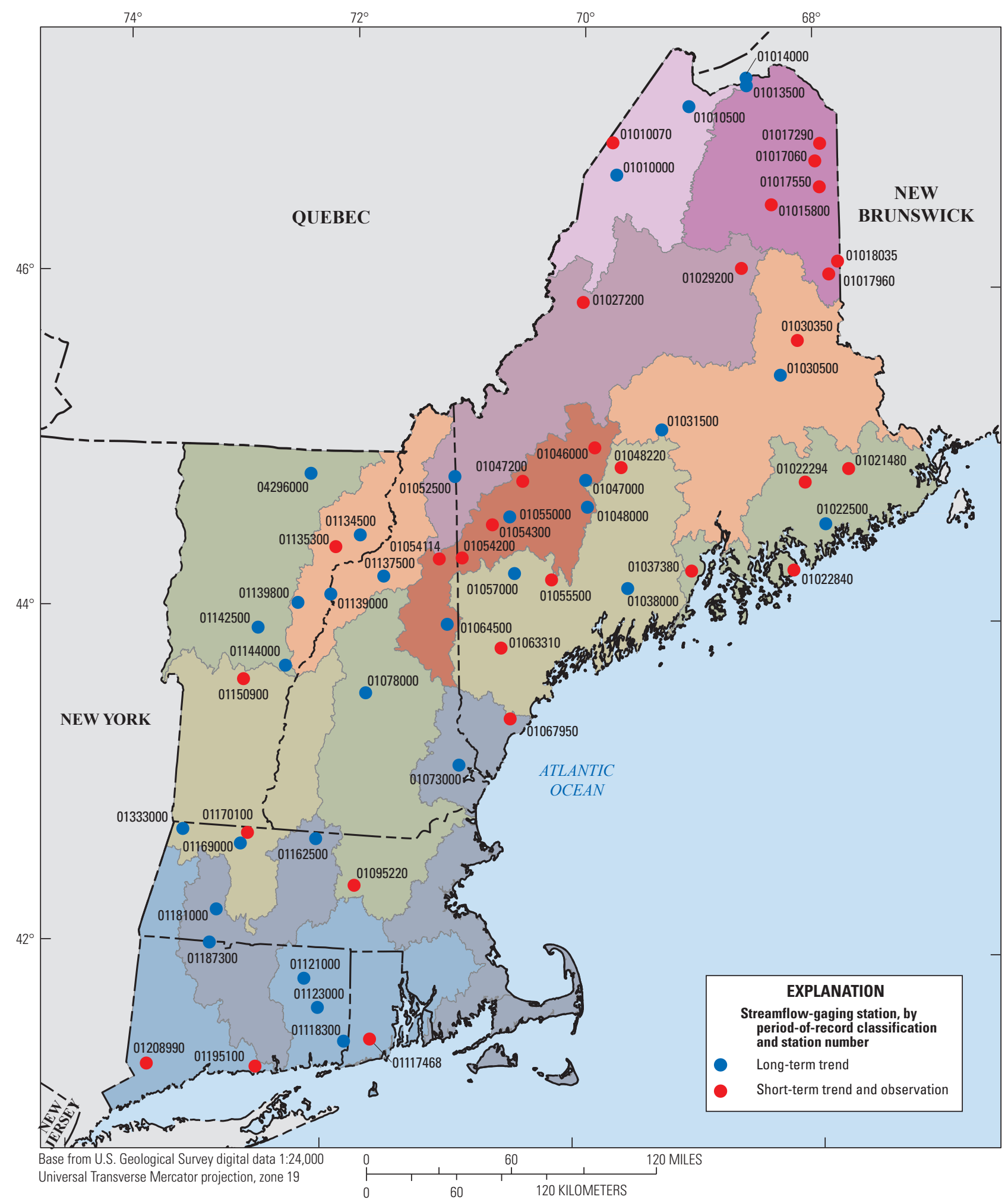

Figure 6. Streamflow-gaging stations in New England that drain relatively natural watersheds. Streamflow-gaging stations have at least 50 years of records for long-term trend testing, at least 30 years for short-term trend testing, and fewer than 30 years for observations. See figure 3 for climate-response regions by color. 
Table 3. Streamflow-gaging stations in New England that drain relatively natural watersheds.

[See figure 6 for station locations. Green fill highlights “True” values. mi², square miles; ft, feet; HCDN-2009, Hydro-Climatic Data Network 2009; ME, Maine; NH, New Hampshire; MA, Massachusetts; RI, Rhode Island; CT, Connecticut; VT, Vermont]

\begin{tabular}{|c|c|c|c|c|c|c|c|c|}
\hline \multirow{2}{*}{$\begin{array}{l}\text { Station } \\
\text { number }\end{array}$} & \multirow{2}{*}{ Station name } & \multirow{2}{*}{$\begin{array}{c}\text { Drainage } \\
\text { area } \\
\left(\mathrm{mi}^{2}\right)\end{array}$} & \multirow{2}{*}{$\begin{array}{c}\text { Eleva- } \\
\text { tion } \\
\text { (ft) }\end{array}$} & \multirow{2}{*}{$\begin{array}{l}\text { HCDN- } \\
2009\end{array}$} & \multicolumn{4}{|c|}{$\begin{array}{c}\text { Meets criteria of record length } \\
\text { and completeness }\end{array}$} \\
\hline & & & & & $\begin{array}{l}30- \\
\text { year }\end{array}$ & $\begin{array}{l}50- \\
\text { year }\end{array}$ & $\begin{array}{l}70- \\
\text { year }\end{array}$ & $\begin{array}{l}90- \\
\text { year }\end{array}$ \\
\hline 01010000 & St. John River at Ninemile Bridge, ME & 1,341 & 931 & No & True & True & False & False \\
\hline 01010070 & Big Black River near Depot Mountain, ME & 171 & 885 & No & False & False & False & False \\
\hline 01010500 & St. John River at Dickey, ME & 2,680 & 590 & No & True & True & False & False \\
\hline 01014000 & St. John River below Fish River at Fort Kent, ME & 5,929 & 476 & No & True & True & True & False \\
\hline 01015800 & Aroostook River near Masardis, ME & 892 & 530 & No & True & True & False & False \\
\hline 01017060 & Hardwood Brook below Glidden Brook near Caribou, ME & 5.7 & 480 & No & False & False & False & False \\
\hline 01017290 & Little Madawaska River at Caribou, ME & 234 & 420 & No & False & False & False & False \\
\hline 01018035 & Meduxnekeag River at Lowery Road near Houlton, ME & 257 & 290 & No & False & False & False & False \\
\hline 01021480 & Old Stream near Wesley, ME & 29.1 & 170 & No & False & False & False & False \\
\hline 01022294 & East Branch Bear Brook near Beddington, ME & 0.042 & 907 & No & False & False & False & False \\
\hline 01022500 & Narraguagus River at Cherryfield, ME & 227 & 44 & Yes & True & True & False & False \\
\hline 01022840 & Otter Creek near Bar Harbor, ME & 1.35 & 90 & No & False & False & False & False \\
\hline 01027200 & North Branch Penobscot River near Pittston Farm, ME & 232 & 1,086 & No & False & False & False & False \\
\hline 01029200 & Seboeis River near Shin Pond, ME & 173 & 512 & No & False & False & False & False \\
\hline 01030350 & Wytopitlock Stream near Wytopitlock, ME & 48.8 & 395 & No & False & False & False & False \\
\hline 01030500 & Mattawamkeag River near Mattawamkeag, ME & 1,418 & 217 & Yes & True & True & True & False \\
\hline 01048000 & Sandy River near Mercer, ME & 516 & 197 & No & False & False & False & False \\
\hline 01048220 & East Branch Wesserunsett Stream near Athens, ME & 19.5 & 500 & No & False & False & False & False \\
\hline 01052500 & Diamond River near Wentworth Location, NH & 152 & 1,259 & Yes & True & True & True & False \\
\hline 01054114 & Peabody River at Gorham, NH & 46.3 & 794 & No & False & False & False & False \\
\hline 01054200 & Wild River at Gilead, ME & 69.6 & 683 & Yes & True & False & False & False \\
\hline 01054300 & Ellis River at South Andover, ME & 130 & 620 & No & False & False & False & False \\
\hline 01055000 & Swift River near Roxbury, ME & 96.9 & 616 & Yes & True & True & True & False \\
\hline 01055500 & Nezinscot River at Turner Center, ME & 169 & 276 & No & False & False & False & False \\
\hline 01057000 & Little Androscoggin River near South Paris, ME & 73.5 & 447 & Yes & True & True & True & False \\
\hline 01063310 & Stony Brook at East Sebago, ME & 0.81 & 275 & No & False & False & False & False \\
\hline 01064500 & Saco River near Conway, NH & 385 & 418 & No & True & True & True & False \\
\hline 01067950 & Kennebunk River near Kennebunk, ME & 26.7 & 70 & No & False & False & False & False \\
\hline 01073000 & Oyster River near Durham, NH & 12.1 & 65 & Yes & True & True & True & False \\
\hline 01078000 & Smith River near Bristol, NH & 85.8 & 450 & Yes & True & True & True & True \\
\hline
\end{tabular}


Table 3. Streamflow-gaging stations in New England that drain relatively natural watersheds._Continued

[See figure 6 for station locations. Green fill highlights "True" values. mi², square miles; ft, feet; HCDN-2009, Hydro-Climatic Data Network 2009; ME, Maine; NH, New Hampshire; MA, Massachusetts; RI, Rhode Island; CT, Connecticut; VT, Vermont]

\begin{tabular}{|c|c|c|c|c|c|c|c|c|}
\hline \multirow{2}{*}{$\begin{array}{l}\text { Station } \\
\text { number }\end{array}$} & \multirow{2}{*}{ Station name } & \multirow{2}{*}{$\begin{array}{c}\text { Drainage } \\
\text { area } \\
\left(\mathrm{mi}^{2}\right)\end{array}$} & \multirow{2}{*}{$\begin{array}{l}\text { Eleva- } \\
\text { tion } \\
(\mathrm{ft})\end{array}$} & \multirow{2}{*}{$\begin{array}{l}\text { HCDN- } \\
2009\end{array}$} & \multicolumn{4}{|c|}{$\begin{array}{l}\text { Meets criteria of record length } \\
\text { and completeness }\end{array}$} \\
\hline & & & & & $\begin{array}{c}\text { 30- } \\
\text { year }\end{array}$ & $\begin{array}{c}50- \\
\text { year }\end{array}$ & $\begin{array}{c}\text { 70- } \\
\text { year }\end{array}$ & $\begin{array}{l}90- \\
\text { year }\end{array}$ \\
\hline 01095220 & Stillwater River near Sterling, MA & 29.1 & 400 & No & False & False & False & False \\
\hline 01117468 & Beaver River near Usquepaug, RI & 8.87 & 108 & Yes & True & False & False & False \\
\hline 01118300 & Pendleton Hill Brook near Clarks Falls, CT & 4.02 & 153 & Yes & True & True & False & False \\
\hline 01121000 & Mount Hope River near Warrenville, CT & 28.6 & 336 & Yes & True & True & True & False \\
\hline 01123000 & Little River near Hanover, CT & 30 & 221 & Yes & True & True & False & False \\
\hline 01135300 & Sleepers River (Site W-5) near St. Johnsbury, VT & 42.9 & 642 & No & False & False & False & False \\
\hline 01134500 & Moose River at Victory, VT & 75.2 & 1,104 & Yes & True & True & False & False \\
\hline 01137500 & Ammonoosuc River at Bethlehem Junction, NH & 87.6 & 1,181 & Yes & True & True & True & False \\
\hline 01139000 & Wells River at Wells River, VT & 98.4 & 506 & Yes & True & True & True & False \\
\hline 01139800 & East Orange Branch at East Orange, VT & 8.95 & 1,180 & Yes & True & True & False & False \\
\hline 01142500 & Ayers Brook at Randolph, VT & 30.5 & 630 & Yes & True & True & True & False \\
\hline 01144000 & White River at West Hartford, VT & 690 & 375 & Yes & True & True & True & True \\
\hline 01150900 & Ottauquechee River near West Bridgewater, VT & 23.4 & 1,149 & Yes & False & False & False & False \\
\hline 01162500 & Priest Brook near Winchendon, MA & 19.4 & 850 & Yes & True & True & True & True \\
\hline 01169000 & North River at Shattuckville, MA & 89 & 458 & Yes & True & True & True & False \\
\hline 01170100 & Green River near Colrain, MA & 41.4 & 435 & Yes & True & False & False & False \\
\hline 01181000 & West Branch Westfield River at Huntington, MA & 94 & 389 & Yes & True & True & True & False \\
\hline 01187300 & Hubbard River near West Hartland, CT & 19.9 & 595 & Yes & True & True & True & False \\
\hline 01195100 & Indian River near Clinton, CT & 5.68 & 35 & Yes & True & False & False & False \\
\hline 01208990 & Saugatuck River near Redding, CT & 21 & 285 & Yes & True & False & False & False \\
\hline 01333000 & Green River at Williamstown, MA & 42.6 & 615 & Yes & True & True & False & False \\
\hline 04296000 & Black River at Coventry, VT & 122 & 710 & Yes & True & True & False & False \\
\hline
\end{tabular}

A recent USGS study of groundwater-level trends in northern New England (Dudley and Hodgkins, 2013) identified wells in Maine, New Hampshire, and Vermont that are minimally affected by human disturbance and thus suitable for a climate-response network. Screening criteria involved the review of well data (time-series plots) and analysis summaries published in annual USGS State Water-Data Reports for non-climate-related effects such as substantial water-use withdrawals or proximity to regulated surface-water bodies. Local USGS groundwater hydrologists were also consulted on the appropriateness of wells. Wells with levels deemed not to be predominantly natural were excluded. In a few cases, clusters of unaffected wells were built close to each other in the same aquifer and had highly correlated $\left(R^{2}>0.80\right)$ records; in these cases only the well with the longest and most complete record was included. Using a criterion of a minimum of 10 years of data (which could be nonconsecutive), Dudley and Hodgkins (2013) identified 77 wells in northern New England that would be suitable for a climate-response network. For the current report, USGS groundwater specialists in southern New England went through a similar process to identify appropriate wells. For New England groundwater wells, a completeness criterion of 80 percent per decade yields 70 and 12 wells appropriate for short-term (30-year) and longterm (50-year) trend testing, respectively (fig. 7; table 4).

Dudley and Hodgkins (2013) examined correlations of groundwater levels with precipitation and streamflow data and found that groundwater levels in May through August correlate strongly with annual (water year) streamflow (fig. 8, for example, from Dudley and Hodgkins, 2013); correlations of groundwater levels with monthly precipitation are less frequent and weaker. Correlations of groundwater levels with streamflow data suggest methods for leveraging the richness of historical streamflow data to extend the record of historical groundwater levels. 


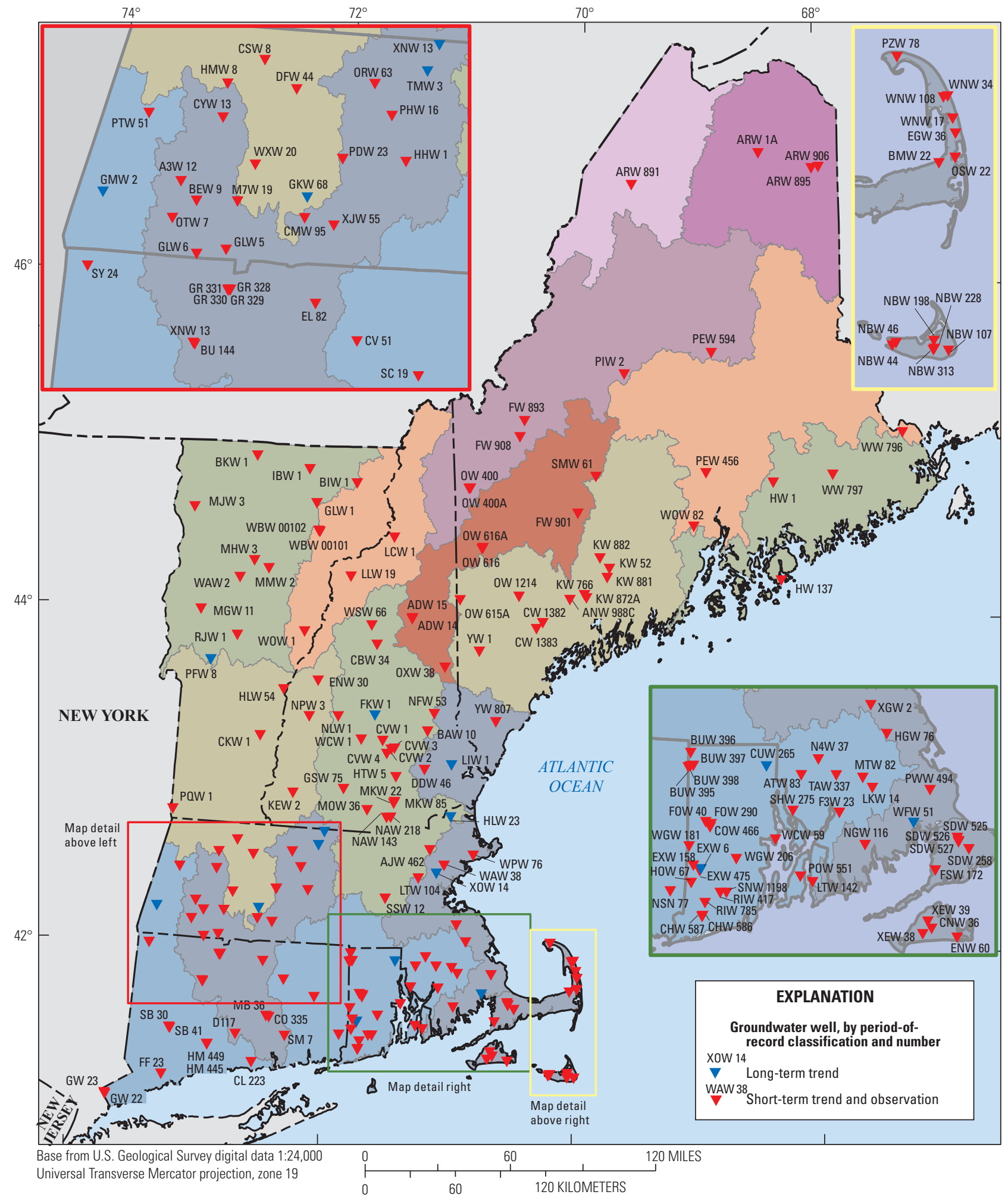

Figure 7. Groundwater wells in New England minimally affected by human disturbance. Wells have at least 50 years of records for long-term trend testing, at least 30 years for short-term trend testing, and fewer than 30 years for observations. See figure 3 for climate-response regions by color. 
Table 4. Groundwater wells in northern New England that meet climate-network criteria.

[See figure 7 for well locations. Years of record, number of years (through water year 2013) when at least one datum point is present. Green fill highlights "TRUE" values. CT, Connecticut; MA, Massachusetts; ME, Maine; NH, New Hampshire; RI, Rhode Island; VT, Vermont]

\begin{tabular}{|c|c|c|c|c|}
\hline \multirow[t]{2}{*}{ Well number } & \multirow[t]{2}{*}{ Well name } & \multirow{2}{*}{$\begin{array}{l}\text { Years } \\
\text { of } \\
\text { record }\end{array}$} & \multicolumn{2}{|c|}{$\begin{array}{l}\text { Meets record } \\
\text { completeness and } \\
\text { length criteria }\end{array}$} \\
\hline & & & 30-year & 50-year \\
\hline 414704072580501 & CT BU143 & 18 & False & False \\
\hline 414649072574401 & CT BU144 & 17 & False & False \\
\hline 411832072325501 & CT CL223 & 22 & False & False \\
\hline 413457072252201 & CT CO335 & 28 & False & False \\
\hline 414833072190301 & CT CV51 & 21 & False & False \\
\hline 412825072410501 & CT D117 & 28 & False & False \\
\hline 415458072291901 & CT EL82 & 21 & False & False \\
\hline 411256073153101 & CT FF23 & 48 & True & False \\
\hline 415649072494801 & CT GR328 & 31 & False & False \\
\hline 415647072495901 & CT GR329 & 30 & False & False \\
\hline 415643072502201 & CT GR330 & 30 & False & False \\
\hline 415653072501701 & CT GR331 & 23 & False & False \\
\hline 410443073414101 & CT GW22 & 12 & False & False \\
\hline 410515073415901 & CT GW23 & 12 & False & False \\
\hline 412423072542801 & CT HM445 & 22 & False & False \\
\hline 412417072541901 & CT HM449 & 21 & False & False \\
\hline 413518072264501 & CT MB36 & 21 & False & False \\
\hline 412931071514201 & CT NSN77 & 22 & False & False \\
\hline 412954073125201 & CT SB30 & 23 & False & False \\
\hline 412935073122701 & CT SB41 & 22 & False & False \\
\hline 414243072040501 & CT SC19 & 28 & False & False \\
\hline 412824072173301 & CT SM7 & 35 & True & False \\
\hline 415956073241501 & CT SY24 & 27 & False & False \\
\hline 421550073025101 & MAA3W12 & 28 & False & False \\
\hline 423641071102501 & MA AJW462 & 37 & True & False \\
\hline 415447071155301 & MA ATW83 & 50 & True & False \\
\hline 421228072585301 & MA BEW9 & 28 & False & False \\
\hline 414630070014901 & MA BMW22 & 51 & True & False \\
\hline 421012072324501 & MA CMW95 & 31 & False & False \\
\hline 412154070404701 & MA CNW36 & 22 & False & False \\
\hline 423809072435601 & MA CSW8 & 49 & True & False \\
\hline 422733072532601 & MA CYW13 & 28 & False & False \\
\hline 423310072355801 & MA DFW44 & 49 & True & False \\
\hline 415125069581501 & MA EGW36 & 39 & True & False \\
\hline 412118070311001 & MA ENW60 & 24 & False & False \\
\hline 414705071045301 & MA F3W23 & 50 & True & False \\
\hline 413522070373601 & MA FSW172 & 39 & False & False \\
\hline 421355072322001 & MA GKW68 & 60 & True & True \\
\hline 420357072511601 & MA GLW5 & 49 & True & False \\
\hline 420259072581701 & MA GLW6 & 49 & True & False \\
\hline
\end{tabular}

Table 4. Groundwater wells in northern New England that meet climate-network criteria.-Continued

[See figure 7 for well locations. Years of record, number of years (through water year 2013) when at least one datum point is present. Green fill highlights "TRUE" values. CT, Connecticut; MA, Massachusetts; ME, Maine; NH, New Hampshire; RI, Rhode Island; VT, Vermont]

\begin{tabular}{|c|c|c|c|c|}
\hline \multirow[t]{2}{*}{ Well number } & \multirow[t]{2}{*}{ Well name } & \multirow{2}{*}{$\begin{array}{l}\text { Years } \\
\text { of } \\
\text { record }\end{array}$} & \multicolumn{2}{|c|}{$\begin{array}{l}\text { Meets record } \\
\text { completeness and } \\
\text { length criteria }\end{array}$} \\
\hline & & & 30-year & 50-year \\
\hline 421316073212801 & MA GMW2 & 63 & True & True \\
\hline 420353070520301 & MA HGW76 & 50 & True & False \\
\hline 422058072085501 & MA HHW1 & 49 & True & False \\
\hline 424841071004101 & MA HLW23 & 54 & True & True \\
\hline 423339072524101 & MA HMW8 & 28 & False & False \\
\hline 415228070554601 & MA LKW14 & 50 & True & False \\
\hline 422627071154002 & MA LTW104 & 49 & True & False \\
\hline 421240072490201 & MA M7W19 & 28 & False & False \\
\hline 415433070583302 & MA MTW82 & 49 & True & False \\
\hline 415812071111101 & MA N4W37 & 50 & True & False \\
\hline 411536069591301 & MA NBW107 & 32 & False & False \\
\hline 411712070022801 & MA NBW198 & 33 & False & False \\
\hline 411555070021901 & MA NBW228 & 38 & True & False \\
\hline 411542070023303 & MA NBW313 & 32 & False & False \\
\hline 411620070113201 & MA NBW44 & 32 & False & False \\
\hline 411645070104401 & MA NBW46 & 35 & True & False \\
\hline 414025070572801 & MA NGW116 & 50 & True & False \\
\hline 423441072170701 & MA ORW63 & 29 & False & False \\
\hline 414726069581601 & MA OSW22 & 39 & True & False \\
\hline 420912073043001 & MA OTW7 & 49 & True & False \\
\hline 422103072241102 & MA PDW23 & 32 & True & False \\
\hline 422103072241103 & MA PDW24 & 31 & False & False \\
\hline 422906072124301 & MA PHW16 & 30 & False & False \\
\hline 422745073112001 & MA PTW51 & 51 & True & False \\
\hline 415217070393102 & MA PWW494 & 28 & False & False \\
\hline 420355070112302 & MA PZW78 & 39 & True & False \\
\hline 413958070281801 & MA SDW258 & 39 & True & False \\
\hline 414219070313601 & MA SDW525 & 12 & False & False \\
\hline 414139070311501 & MA SDW526 & 12 & False & False \\
\hline 414124070311401 & MA SDW527 & 12 & False & False \\
\hline 414714071175901 & MA SHW275 & 50 & True & False \\
\hline 421851071312601 & MA SSW12 & 25 & False & False \\
\hline 415457071060101 & MA TAW337 & 50 & True & False \\
\hline 423717072043101 & MA TMW3 & 56 & True & True \\
\hline 423115071032001 & MA WAW38 & 49 & True & False \\
\hline 414518070435701 & MA WFW51 & 55 & True & True \\
\hline 415732070000401 & MA WNW108 & 36 & True & False \\
\hline 415353069585401 & MA WNW17 & 51 & True & False \\
\hline 415722070010001 & MA WNW34 & 39 & True & False \\
\hline 423505070491702 & MA WPW76 & 49 & True & False \\
\hline
\end{tabular}


Table 4. Groundwater wells in northern New England that meet climate-network criteria.-Continued

[See figure 7 for well locations. Years of record, number of years (through water year 2013) when at least one datum point is present. Green fill highlights "TRUE" values. CT, Connecticut; MA, Massachusetts; ME, Maine; NH, New Hampshire; RI, Rhode Island; VT, Vermont]

\begin{tabular}{|c|c|c|c|c|}
\hline \multirow[t]{2}{*}{ Well number } & \multirow[t]{2}{*}{ Well name } & \multirow{2}{*}{$\begin{array}{l}\text { Years } \\
\text { of } \\
\text { record }\end{array}$} & \multicolumn{2}{|c|}{$\begin{array}{l}\text { Meets record } \\
\text { completeness and } \\
\text { length criteria }\end{array}$} \\
\hline & & & 30 -year & 50-year \\
\hline 421923072451001 & MA WXW20 & 27 & False & False \\
\hline 412304070382001 & MA XEW38 & 22 & False & False \\
\hline 412434070392601 & MA XEW39 & 22 & False & False \\
\hline 420954070564501 & MA XGW2 & 49 & True & False \\
\hline 420905072254001 & MA XJW55 & 49 & True & False \\
\hline 424204072015201 & MA XNW13 & 74 & True & True \\
\hline 424752071315202 & MA XNW13 & 27 & False & False \\
\hline 424800071295301 & MA XNW13 & 50 & True & False \\
\hline 424810073160401 & MA XNW13 & 49 & True & False \\
\hline 422819071065701 & MA XOW14 & 74 & True & True \\
\hline 440730070035304 & ME ANW988C & 14 & False & False \\
\hline 464807068284401 & ME ARW1A & 15 & False & False \\
\hline 463642069344601 & ME ARW891 & 26 & False & False \\
\hline 464234068010401 & ME ARW895 & 15 & False & False \\
\hline 464259067572901 & ME ARW906 & 25 & False & False \\
\hline 435902070171301 & ME CW1382 & 11 & False & False \\
\hline 435653070201801 & ME CW1383 & 11 & False & False \\
\hline 451128070280301 & ME FW893 & 15 & False & False \\
\hline 443831070002601 & ME FW901 & 14 & False & False \\
\hline 450539070301301 & ME FW908 & 12 & False & False \\
\hline 444950068220601 & ME HW1 & 16 & False & False \\
\hline 441440068182701 & ME HW137 & 20 & False & False \\
\hline 441849069442001 & ME KW52 & 45 & False & False \\
\hline 440918069564001 & ME KW766 & 37 & True & False \\
\hline 440810069553601 & ME KW872A & 35 & True & False \\
\hline 441533069452401 & ME KW881 & 13 & False & False \\
\hline 442233069490701 & ME KW882 & 11 & False & False \\
\hline 440823070291501 & ME OW1214 & 34 & True & False \\
\hline 444637070552301 & ME OW400 & 52 & False & False \\
\hline 443647070552302 & ME OW400A & 24 & False & False \\
\hline 440642070583402 & ME OW615A & 11 & False & False \\
\hline 442515070481001 & ME OW616 & 14 & False & False \\
\hline 442515070481002 & ME OW616A & 11 & False & False \\
\hline 445319068560101 & ME PEW456 & 36 & True & False \\
\hline 453629068531801 & ME PEW594 & 21 & False & False \\
\hline 452829069322101 & ME PIW2 & 13 & False & False \\
\hline 445148069513301 & ME SMW61 & 24 & False & False \\
\hline 443407069020901 & ME WOW82 & 11 & False & False \\
\hline 450713067162801 & ME WW796 & 34 & True & False \\
\hline 445227067520101 & ME WW797 & 28 & False & False \\
\hline
\end{tabular}

Table 4. Groundwater wells in northern New England that meet climate-network criteria.-Continued

[See figure 7 for well locations. Years of record, number of years (through water year 2013) when at least one datum point is present. Green fill highlights "TRUE" values. CT, Connecticut; MA, Massachusetts; ME, Maine; $\mathrm{NH}$, New Hampshire; RI, Rhode Island; VT, Vermont]

\begin{tabular}{|c|c|c|c|c|}
\hline \multirow[t]{2}{*}{ Well number } & \multirow[t]{2}{*}{ Well name } & \multirow{2}{*}{$\begin{array}{l}\text { Years } \\
\text { of } \\
\text { record }\end{array}$} & \multicolumn{2}{|c|}{$\begin{array}{c}\text { Meets record } \\
\text { completeness and } \\
\text { length criteria }\end{array}$} \\
\hline & & & 30-year & 50-year \\
\hline 434822070482501 & ME YW1 & 23 & False & False \\
\hline 432310070393301 & ME YW807 & 26 & False & False \\
\hline 435948071220301 & NH ADW14 & 19 & False & False \\
\hline 435948071220302 & NH ADW15 & 20 & False & False \\
\hline 431916071125901 & NH BAW10 & 18 & False & False \\
\hline 434952071390901 & NH CBW34 & 21 & False & False \\
\hline 431526071345501 & NH CVW1 & 26 & False & False \\
\hline 431224071303601 & NH CVW2 & 50 & True & False \\
\hline 431248071290201 & NH CVW3 & 22 & False & False \\
\hline 431049071324301 & NH CVW4 & 47 & True & False \\
\hline 430527071140101 & NH DDW46 & 22 & False & False \\
\hline 433616072074001 & NH ENW30 & 20 & False & False \\
\hline 432428071390701 & NH FKW1 & 47 & True & False \\
\hline 425744071532001 & NH GSW75 & 19 & False & False \\
\hline 430235071275501 & NH HTW5 & 49 & True & False \\
\hline 425543072175801 & NH KEW2 & 51 & True & False \\
\hline 442830071321001 & NH LCW1 & 47 & True & False \\
\hline 430721071005001 & NH LIW1 & 58 & True & True \\
\hline 441401071531501 & NH LLW19 & 21 & False & False \\
\hline 425303071283701 & NH MKW22 & 28 & False & False \\
\hline 425339071281501 & NH MKW85 & 17 & False & False \\
\hline 425024071413001 & NH MOW36 & 48 & False & False \\
\hline 432534071095601 & NH NFW53 & 22 & False & False \\
\hline 432343071570901 & NH NLW1 & 66 & True & True \\
\hline 432322072112401 & NH NPW3 & 20 & False & False \\
\hline 434221071051501 & NH OXW38 & 20 & False & False \\
\hline 431540071452801 & NH WCW1 & 48 & True & False \\
\hline 435645071420520 & NH WSW66 & 19 & False & False \\
\hline 415546071474701 & RI BUW395 & 22 & False & False \\
\hline 415847071471401 & RI BUW396 & 22 & False & False \\
\hline 415606071462201 & RI BUW397 & 21 & False & False \\
\hline 415559071471201 & RI BUW398 & 21 & False & False \\
\hline 412434071422401 & RI CHW586 & 22 & False & False \\
\hline 412424071423601 & RI CHW587 & 21 & False & False \\
\hline 414315071410701 & RI COW466 & 22 & False & False \\
\hline 415626071254601 & RI CUW265 & 68 & True & True \\
\hline 413505071452801 & RI EXW158 & 30 & False & False \\
\hline 413358071433801 & RI EXW475 & 33 & True & False \\
\hline 413423071431901 & RI EXW6 & 66 & True & True \\
\hline 414357071405101 & RI FOW290 & 22 & False & False \\
\hline
\end{tabular}


Table 4. Groundwater wells in northern New England that meet climate-network criteria.-Continued

[See figure 7 for well locations. Years of record, number of years (through water year 2013) when at least one datum point is present. Green fill highlights "TRUE" values. CT, Connecticut; MA, Massachusetts; ME, Maine; NH, New Hampshire; RI, Rhode Island; VT, Vermont]

\begin{tabular}{|c|c|c|c|c|}
\hline \multirow[t]{2}{*}{ Well number } & \multirow[t]{2}{*}{ Well name } & \multirow{2}{*}{$\begin{array}{l}\text { Years } \\
\text { of } \\
\text { record }\end{array}$} & \multicolumn{2}{|c|}{$\begin{array}{l}\text { Meets record } \\
\text { completeness and } \\
\text { length criteria }\end{array}$} \\
\hline & & & 30 -year & 50-year \\
\hline 414420071422301 & RI FOW40 & 30 & False & False \\
\hline 413126071455501 & RI HOW67 & 30 & False & False \\
\hline 413220071115501 & RI LTW142 & 21 & False & False \\
\hline 413325071152401 & RI POW551 & 22 & False & False \\
\hline 412932071374302 & RI RIW417 & 38 & True & False \\
\hline 412718071415201 & RI RIW785 & 24 & False & False \\
\hline 412935071355701 & RI SNW1198 & 21 & False & False \\
\hline 414106071223901 & RI WCW59 & 31 & False & False \\
\hline 413907071465001 & RI WGW181 & 46 & True & False \\
\hline 413645071332901 & RI WGW206 & 31 & False & False \\
\hline 444731071514701 & VT BIW1 & 47 & True & False \\
\hline 445603072422901 & VT BKW1 & 42 & False & False \\
\hline 431551072350601 & VT CKW1 & 47 & True & False \\
\hline 443952072114001 & VT GLW1 & 46 & True & False \\
\hline 433240072242901 & VT HLW54 & 44 & True & False \\
\hline 445158072155001 & VT IBW1 & 13 & False & False \\
\hline 440016073070901 & VT MGW11 & 33 & True & False \\
\hline 441829072413901 & VT MHW3 & 25 & False & False \\
\hline 443646073124901 & VT MJW3 & 52 & False & False \\
\hline 441552072341901 & VT MMW2 & 29 & False & False \\
\hline 434217073010601 & VT PFW8 & 55 & True & True \\
\hline 435129072483301 & VT RJW1 & 42 & False & False \\
\hline 441215072483101 & VT WAW2 & 35 & False & False \\
\hline 442939072093701 & VT WBW00101 & 18 & False & False \\
\hline 442939072093702 & VT WBW00102 & 18 & False & False \\
\hline 435343072151801 & VT WOW1 & 46 & True & False \\
\hline
\end{tabular}

\section{Lake Ice}

The key historical measure of lake ice (and the only commonly available measure of lake ice in New England) is lake ice-out date - the annual date in spring when winter ice cover leaves a lake (Hodgkins and others, 2002; Hodgkins, 2013). This is normally defined as the date at which substantial ice is no longer visible for a lake or the date at which a boat can traverse between set points. In Northern Hemisphere mid-latitude areas such as New England, ice-out dates can serve as useful indicators of late-winter and earlyspring climate change. A remarkable amount of lake ice-out data has been recorded and saved in New England during the past two centuries, mostly in northern New England. Lake ice-out dates for many lakes in New England have been compiled (Hodgkins and James, 2002; Hodgkins, 2010b) and analyzed (Hodgkins and others, 2002; Hodgkins, 2013); data from additional lakes have been recently compiled. There are 37 lakes that have at least 80-percent data completeness for each decade from 1960 to 2013 (11 of 13 years for 2000 to 2012). As of 2012, 5 lakes have 165 years or more of data, and another 14 have more than 110 years of data. Long-term lake ice-out data for many lakes in New England represent a unique 


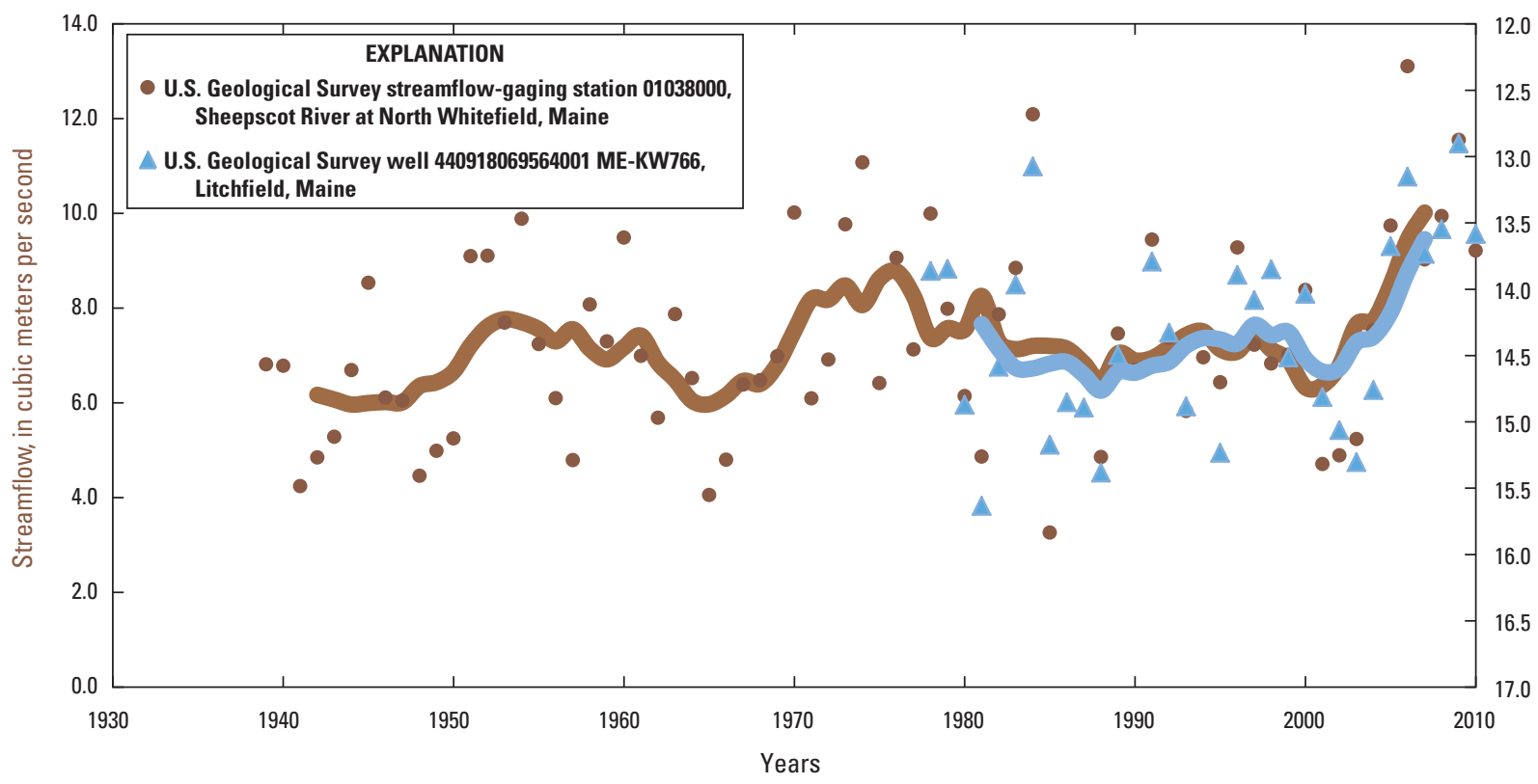

Figure 8. Relation of August groundwater levels and annual mean streamflows; modified from Dudley and Hodgkins (2013, fig. 7). Curves are 7-year moving averages.

hydroclimatic dataset that is useful for continued monitoring of hydrologic response to regional climate change. These lakes would be used in a hydrologic climate-response data network. An additional seven lakes with 30 to 50 years of record would augment the network for short-term trend analysis (fig. 9; table 5). These lakes are appropriate for inclusion in the network on the basis of 80-percent data completeness for each decade from 1980 to 2013 (11 of 13 years for 2000-2012). Many more lakes in northern New England have short records or records with large gaps. These lakes could also be included in the network when their records approach useful lengths (and meet completeness criteria).

Most of the lakes in this study are in rural areas (Hodgkins and others, 2002). Lakes in the northern parts of Maine, New Hampshire, and Vermont generally drain remote, undeveloped forests. Lakes in more southerly areas of northern New England generally drain rural areas with forests, some low-density residential development, and small towns. Lake Auburn is near a relatively small urban area (Auburn, Maine); Houghtons and Ponkapoag Ponds outside Boston, Massachusetts, are near a large urban area. There are no lakes currently known with substantial amounts (more than 10 years) of ice-out data from nonurban lakes in southern New England. The ice-out dates for lakes near urban areas could be affected by urban heat-island temperature effects.

Ice-out definitions for individual lakes can vary over time and among observers (Hodgkins and others, 2002). Twenty years or more of overlapping data from independent observers were available for six lakes. On the basis of this limited dataset, Hodgkins and others (2002) concluded that observer biases (different people on the same lake recording different ice-out dates for the same year) of more than 1 day are unlikely on relatively round lakes. In contrast, 3- to 4-day biases can occur on long, narrow lakes if the observation locations are on opposite ends of the lake. On two long, narrow lakes with north-south axes, the observer of later iceout dates was located at the northern end of the lakes. These observational biases could result in large biases in ice-out trends over time at individual lakes. At a large number of lakes, however, it is unlikely that observer-location biases would tend to bias trend tests in any one direction. For example, for a large number of lakes there is no reason to expect that people observed less recent ice-outs at the southern end of lakes and more recent ice-outs at the northern end of lakes.

\section{Snowpack}

Long-term snowpack data are mostly limited to Maine, but given its importance in New England hydrology, snowpack is included as a variable in the New England hydrologic climate-response network. The following text is from Hodgkins and others (2009, p. 13):

"Key snowpack variables are the magnitude of late-winter water equivalent, depth, and density for selected dates. Emergency management and response agencies, flood-forecasting agencies, 


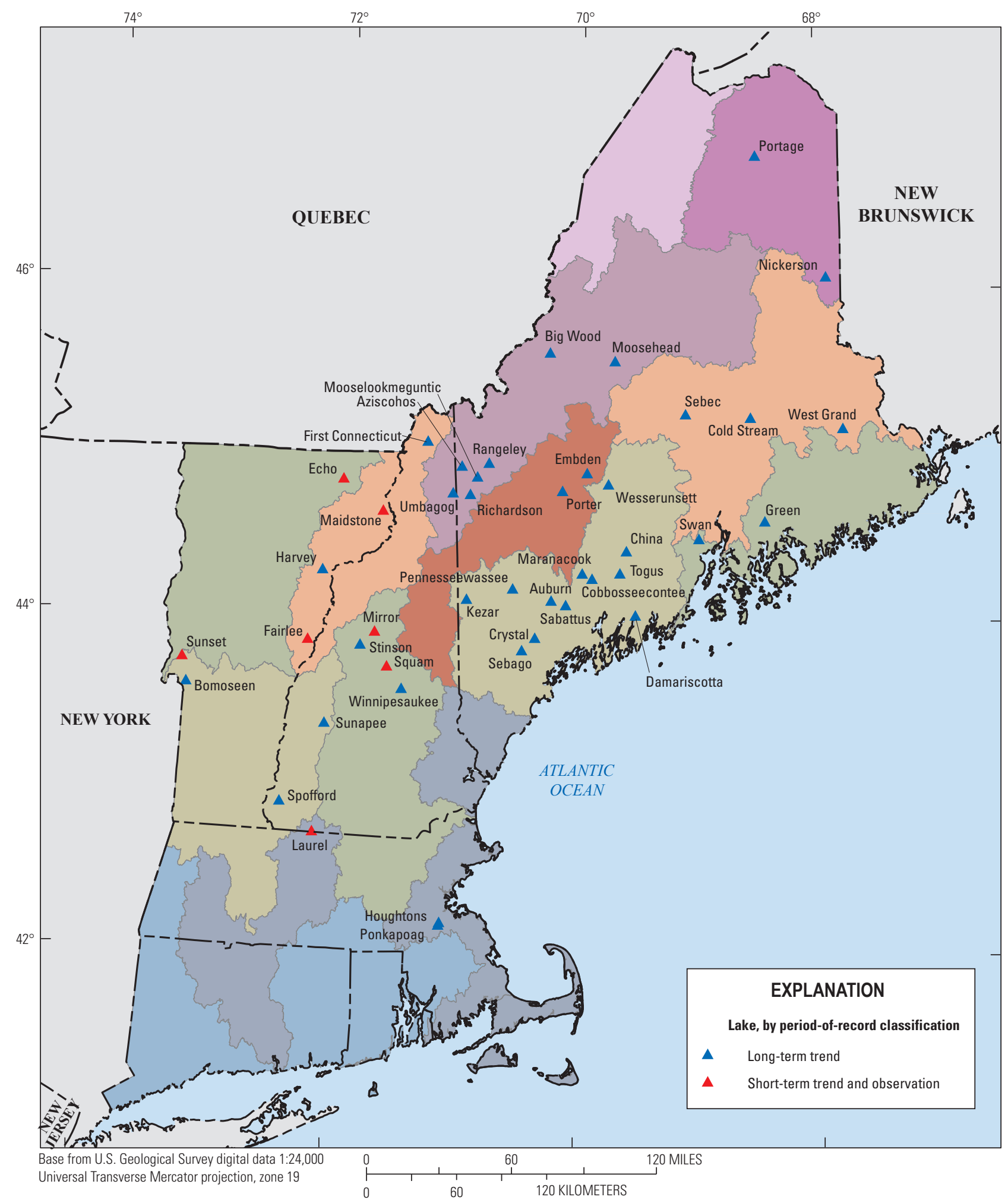

Figure 9. Lakes in New England with substantial amounts of ice-out data. Sites have at least 50 years of records for long-term trend testing, at least 30 years for short-term trend testing, and fewer than 30 years for observations. See figure 3 for climateresponse regions by color. See table 5 for full lake names. 
Table 5. Lakes in New England with substantial amounts of ice-out data.

[See figure 9 for lake locations. ft, feet; MA, Massachusetts; ME, Maine; NH, New Hampshire; VT, Vermont]

\begin{tabular}{|c|c|c|}
\hline Lake name and location & $\begin{array}{c}\text { Elevation } \\
\text { (ft) }\end{array}$ & $\begin{array}{c}\text { Period of record } \\
\text { (years) }\end{array}$ \\
\hline Houghton's Pond near Ponkapoag, MA & 161 & 126 \\
\hline Ponkapoag Pond at Ponkapoag, MA & 161 & 126 \\
\hline Aziscohos Lake at Aziscohos Dam, ME & 1,513 & 97 \\
\hline Big Wood Pond at Jackman, ME & 1,161 & 92 \\
\hline China Lake at East Vassalboro, ME & 194 & 86 \\
\hline Cobbosseecontee Lake near Winthrop Center, ME & 164 & 171 \\
\hline Cold Stream Pond near Enfield, ME & 190 & 67 \\
\hline Crystal Lake at Dry Mills, ME & 308 & 53 \\
\hline Damariscotta Lake at Damariscotta Mills, ME & 46 & 175 \\
\hline Embden Pond near North Anson, ME & 413 & 88 \\
\hline Green Lake at Lakewood, ME & 167 & 78 \\
\hline Kezar Lake near Lovell, ME & 374 & 112 \\
\hline Lake Auburn at East Auburn, ME & 259 & 170 \\
\hline Lake Wesserunsett at East Madison, ME & 335 & 125 \\
\hline Maranacook Lake at Winthrop, ME & 210 & 88 \\
\hline Moosehead Lake at Moosehead, ME & 1,011 & 165 \\
\hline Mooselookmeguntic Lake at Upper Dam, ME & 1,453 & 111 \\
\hline Nickerson Lake near Carys Mills, ME & 377 & 64 \\
\hline Pennesseewassee Lake at Norway, ME & 394 & 137 \\
\hline Portage Lake near Portage, ME & 610 & 87 \\
\hline Porter Lake near New Vineyard, ME & 633 & 74 \\
\hline Rangeley Lake at Oquossoc, ME & 1,519 & 133 \\
\hline Richardson Lakes at Middle Dam, ME & 1,444 & 131 \\
\hline Sabattus Pond at Sabattus, ME & 236 & 87 \\
\hline Sebago Lake near North Windham, ME & 266 & 172 \\
\hline Sebec Lake at Sebec, ME & 305 & 130 \\
\hline Swan Lake at Swanville, ME & 203 & 122 \\
\hline Togus Pond near West Windsor, ME & 180 & 71 \\
\hline Umbagog Lake near Upton, ME & 1,240 & 122 \\
\hline West Grand Lake at Grand Lake Stream, ME & 303 & 135 \\
\hline First Connecticut Lake near Pittsburg, NH & 1,636 & 92 \\
\hline Lake Winnipesaukee at Interlaken Park, NH & 515 & 126 \\
\hline Laurel Lake near Fitzwilliam Depot, NH & 1,099 & 50 \\
\hline Mirror Lake at Hubbard Brook Experimental Forest at West Thornton, NH & 705 & 41 \\
\hline Spofford Lake at Spofford, NH & 748 & 70 \\
\hline Squam Lake at Holderness, NH & 597 & 35 \\
\hline Stinson Lake at Stinson Lake, NH & 1,355 & 76 \\
\hline Sunapee Lake at Sunapee, NH & 1,090 & 144 \\
\hline Echo Lake at East Charleston, VT & 1,253 & 43 \\
\hline Harvey Lake at West Barnet, VT & 892 & 62 \\
\hline Lake Bomoseen near Fair Haven, VT & 427 & 54 \\
\hline Lake Fairlee near West Fairlee, VT & 705 & 37 \\
\hline Maidstone Lake at Bullthroat, VT & 1,302 & 39 \\
\hline Sunset Lake near Hortonia, VT & 508 & 37 \\
\hline
\end{tabular}


people who live near streams, and many waterdependent industries need to know how much water to expect each year from snowmelt. Primarily for this reason, the Maine Cooperative Snow Survey Program, run jointly by the Maine Geological Survey (MGS) and the USGS, compiles snowpack data collected by the USGS, the MGS, the National Weather Service, electric-power utilities, waterpower companies, pulp and paper companies, and others on a regular basis (currently weekly, historically biweekly) in late winter and spring (Hodgkins and Dudley, 2006a).

"The depth and water equivalent (the depth of water that would result if the snowpack were melted) of the snowpack have been measured at selected sites in Maine since the early part of the 20th century [Hodgkins, Dudley, and Loiselle, 2005]. Most of the sites are in flat or gently sloping areas of mixed hardwood and conifer forest. Measurements are not made near conifers. Most data are collected at locations with an elevation of less than 2,000 ft. Historical site information for the sites in this report is extremely limited. Some sites have been moved away from the local effects of development, extensive logging, or unacceptable amounts of conifer growth.

"Snowpack depth and water-equivalent data were analyzed for those sites with data spanning at least 50 years through 2004 (Hodgkins and Dudley, 2006a). The exact date of sampling at a site varies from year to year. Data for a site commonly are not available for every year for a given sampling window. Sampling windows were defined as 15-day windows centered on February 15, March 1, March 15, April 1, April 15, and May 1. To be included for analysis, the sites were required to have at least 50-percent complete data for the first and second halves of their record for at least one sampling window. Thirty-seven sites in and near Maine met the described criteria. Historical snow depth and water-equivalent data for these sites are reported in [Hodgkins, Dudley, and Loiselle (2005)] as follows:

"Because sampling windows were used, it is possible to have biased sampling over time at sites (Hodgkins and Dudley, 2006a). If sampling tends to be earlier or later over time, any significant trends in the snowpack data could be the result of sampling bias. All data sets (individual sites for each applicable sampling window) that met the criteria for inclusion were tested for significant changes over time in the date of sampling. Data from many sites sampled during the March 1 sampling window were found to be biased, with many sampling dates prior to March 1 early in the record and many dates after March 1 later in the record. Fourteen sites were eliminated because of significant bias in the date of sampling. Data from 23 sites with data for at least one sampling window did not show significant sampling bias and were considered appropriate for use in computing climate-related trends over time [fig. 10; table 6]. These sites would be the starting point for sites to be included in a hydrologic climate-response data network."

It would be desirable to add shorter-term snowpack sites, but this requires an amount of analysis beyond the scope of this report. It would also be desirable to have additional snowpack sites outside of Maine, particularly in areas of regular substantial snowpack.

\section{Meteorological Stations}

Precipitation and air temperature trends and variability are important to streamflow, groundwater, lake ice-out, and snowpack trends and variability. The relative influence of precipitation and air temperature varies by season. Many recent climate-change-related studies have made use of the U.S. Historical Climatology Network (USHCN) monthly dataset to analyze meteorological trends; the most recent dataset available is version 2 (Quinlan and others, 1987; Menne and others, 2009). The USHCN data are qualityassured and evaluated on the basis of record length and completeness; data are subject to time-of-observation bias adjustments (Karl and others 1986; Vose and others, 2003), homogeneity testing, and adjustment procedures to account for non-climate-related changes in the record such as instrument and station location changes (Menne and Williams, 2009). Missing data are estimated by using weighted averages of highly correlated neighboring data. The 44 USHCN stations in New England are shown in table 7 and figure 11; stations have a minimum of 99 years of record through 2012 and are appropriate for the analysis of long-term trends.

\section{Process-Based Studies}

An important part of establishing a hydrologic climateresponse network in New England would be to identify basins that are appropriate for use in process-based studies designed to improve understanding of and predict hydrologic and ecosystem change. The combination of extensive historical hydrologic data, ecological data, and deterministic watershed modeling would greatly increase our understanding of the effects of climate change on hydrologic components and ecosystem health.

For each of the 14 lower tier regions in the proposed hydrologic climate-response network, a representative basin (in geology, land cover, and other characteristics) that has extensive historical data for multiple hydrologic components would be identified; potential sites are indicated in table 8 and 


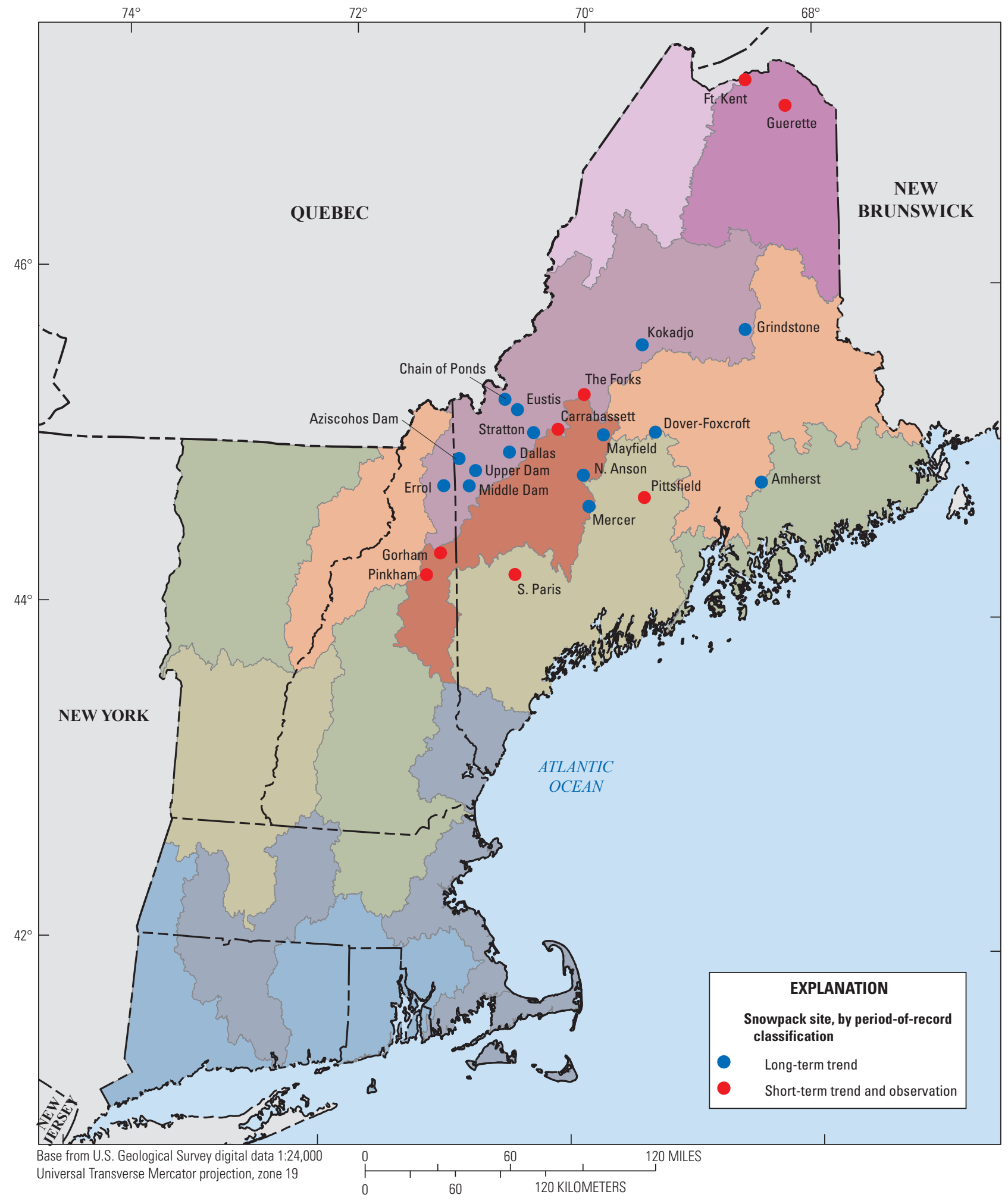

Figure 10. Location of long-term snowpack sites in New England. Sites have at least 50 years of records for long-term trend testing, at least 30 years for short-term trend testing, and fewer than 30 years for observations. See figure 3 for climateresponse regions by color. See table 6 for full site names. 
Table 6. Long-term snowpack sites in New England.

[See figure 10 for site locations. Abbreviations in site name are part of the official name. All sites are in Maine, unless otherwise noted. A sampling window is defined as a 15-day period centered on the date shown. NH, New Hampshire]

\begin{tabular}{|c|c|c|c|}
\hline Site number & Site name & $\begin{array}{c}\text { Map name } \\
\text { (in fig. 10) }\end{array}$ & Sampling window \\
\hline 1002 & The Forks & The Forks & 1-Mar \\
\hline 1004 & Grindstone & Grindstone & 1-Mar \\
\hline 1015 & Mercer & Mercer & 1-Mar \\
\hline 1020 & Dover-Foxcroft (B) & Dover-Foxcroft & 1-Mar \\
\hline 1024 & North Anson & N. Anson & 1-Mar \\
\hline 1044 & Pinkham Notch (UWP), NH & Pinkham & 1-Mar \\
\hline 1050 & Pittsfield (B) & Pittsfield & 1-Mar \\
\hline 1053 & Gorham, NH & Gorham & 1-Mar \\
\hline 1066 & Mayfield (Bingham Upper) & Mayfield & 1-Mar \\
\hline 1292 & Kokadjo (KWP) & Kokadjo & 1-Mar \\
\hline 1002 & The Forks & The Forks & 15-Mar \\
\hline 1018 & Amherst (BH) & Amherst & 15-Mar \\
\hline 1022 & Fort Kent & Ft. Kent & 15-Mar \\
\hline 1024 & North Anson & N. Anson & 15-Mar \\
\hline 1027 & Errol/Errol Dam (UWP), NH & Errol & 15-Mar \\
\hline 1028 & Aziscohos/Aziscohos Dam (UWP) & Aziscohos & 15-Mar \\
\hline 1030 & Middle Dam (UWP) & Middle Dam & 15-Mar \\
\hline 1031 & Upper Dam (UWP) & Upper Dam & 15-Mar \\
\hline 1046 & South Paris & S. Paris & 15-Mar \\
\hline 1061 & Guerrette & Guerrette & 15-Mar \\
\hline 1100 & Eustis (KWP) & Eustis & 15-Mar \\
\hline 1246 & Stratton (KWP) & Stratton & 15-Mar \\
\hline 1288 & Carrabassett (KWP) & Carrabassett & 15-Mar \\
\hline 1289 & Dallas (KWP) & Dallas & 15-Mar \\
\hline 1290 & Chain of Ponds (KWP) & Chain of Ponds & 15-Mar \\
\hline 1027 & Errol/Errol Dam (UWP), NH & Errol & 1-Apr \\
\hline 1028 & Aziscohos/Aziscohos Dam (UWP) & Aziscohos & 1-Apr \\
\hline 1030 & Middle Dam (UWP) & Middle Dam & 1-Apr \\
\hline 1031 & Upper Dam (UWP) & Upper Dam & 1-Apr \\
\hline
\end{tabular}


Table 7. Long-term meteorological stations in New England.

[See figure 11 for station locations. Location of meteorological stations shown in figure 8. Abbreviations in site name are part of the official name. ft, feet; PPOR, years of precipitation record through 2012; TPOR, years of air temperature record through 2012; CT, Connecticut; ME, Maine; MA, Massachusetts; NH, New Hampshire; RI, Rhode Island; VT, Vermont]

\begin{tabular}{|c|c|c|c|c|}
\hline \multicolumn{2}{|r|}{ Meteorological station } & \multirow{2}{*}{$\begin{array}{c}\text { Elevation } \\
\text { (ft) }\end{array}$} & \multirow{2}{*}{$\begin{array}{l}\text { PPOR } \\
\text { (years) }\end{array}$} & \multirow{2}{*}{$\begin{array}{c}\text { TPOR } \\
\text { (years) }\end{array}$} \\
\hline Number & Name & & & \\
\hline 062658 & CT 062658 FALLS VILLAGE & 550 & 117 & 117 \\
\hline 063207 & CT 063207 GROTON & 40 & 117 & 117 \\
\hline 067970 & CT 067970 STAMFORD $5 \mathrm{~N}$ & 190 & 107 & 117 \\
\hline 068138 & CT 068138 STORRS & 650 & 117 & 117 \\
\hline 170100 & ME 170100 ACADIA NP & 470 & 117 & 117 \\
\hline 170814 & ME 170814 BRASSUA DAM & 1,060 & 113 & 115 \\
\hline 171628 & ME 171628 CORINNA & 297 & 117 & 117 \\
\hline 172426 & ME 172426 EASTPORT & 85 & 117 & 117 \\
\hline 172765 & ME 172765 FARMINGTON & 420 & 117 & 117 \\
\hline 173046 & ME 173046 GARDINER & 140 & 117 & 117 \\
\hline 173944 & ME 173944 HOULTON 5N & 390 & 109 & 117 \\
\hline 174566 & ME 174566 LEWISTON & 180 & 117 & 117 \\
\hline 175304 & ME 175304 MILLINOCKET & 360 & 117 & 117 \\
\hline 176905 & ME 176905 PORTLAND JETPORT & 45 & 117 & 117 \\
\hline 176937 & ME 176937 PRESQUE ISLE & 599 & 117 & 114 \\
\hline 179891 & ME 179891 WOODLAND & 140 & 117 & 117 \\
\hline 190120 & MA 190120 AMHERST & 150 & 117 & 117 \\
\hline 190535 & MA 190535 BEDFORD & 160 & 117 & 117 \\
\hline 190736 & MA 190736 BLUE HILL & 630 & 117 & 117 \\
\hline 193213 & MA 193213 GREAT BARRINGTON 5 SW & 817 & 99 & 117 \\
\hline 194105 & MA 194105 LAWRENCE & 50 & 117 & 117 \\
\hline 195246 & MA 195246 NEW BEDFORD & 70 & 117 & 117 \\
\hline 196486 & MA 196486 PLYMOUTH-KINGSTON & 45 & 117 & 117 \\
\hline 196681 & MA 196681 PROVINCETOWN & 20 & 117 & 117 \\
\hline 196783 & MA 196783 READING & 90 & 117 & 117 \\
\hline 198367 & MA 198367 TAUNTON & 20 & 117 & 117 \\
\hline 198757 & MA 198757 WALPOLE 2 & 165 & 117 & 117 \\
\hline 199316 & MA 199316 WEST MEDWAY & 210 & 117 & 117 \\
\hline 270706 & NH 270706 BETHLEHEM 2 & 1,180 & 117 & 117 \\
\hline 272174 & NH 272174 DURHAM & 80 & 117 & 117 \\
\hline 272999 & NH 272999 FIRST CONNECTICUT LAKE & 1,660 & 117 & 110 \\
\hline 273850 & NH 273850 HANOVER & 603 & 117 & 117 \\
\hline 274399 & NH 274399 KEENE & 520 & 117 & 117 \\
\hline 370896 & RI 370896 BLOCK ISLAND STATE AP & 110 & 117 & 117 \\
\hline 374266 & RI 374266 KINGSTON & 114 & 117 & 117 \\
\hline 376698 & RI 376698 PROVIDENCE WSO AP & 51 & 117 & 117 \\
\hline 431081 & VT 431081 BURLINGTON WSO AP & 330 & 117 & 117 \\
\hline 431243 & VT 431243 CAVENDISH & 842 & 117 & 117 \\
\hline 431360 & VT 431360 CHELSEA & 800 & 117 & 117 \\
\hline 431580 & VT 431580 CORNWALL & 345 & 117 & 117 \\
\hline 432769 & VT 432769 ENOSBURG FALLS & 420 & 117 & 117 \\
\hline 437054 & VT 437054 SAINT JOHNSBURY & 700 & 117 & 117 \\
\hline 437607 & VT 437607 SOUTH HERO & 110 & 117 & 117 \\
\hline 437612 & VT 437612 SOUTH LINCOLN & 1,341 & 117 & 117 \\
\hline
\end{tabular}




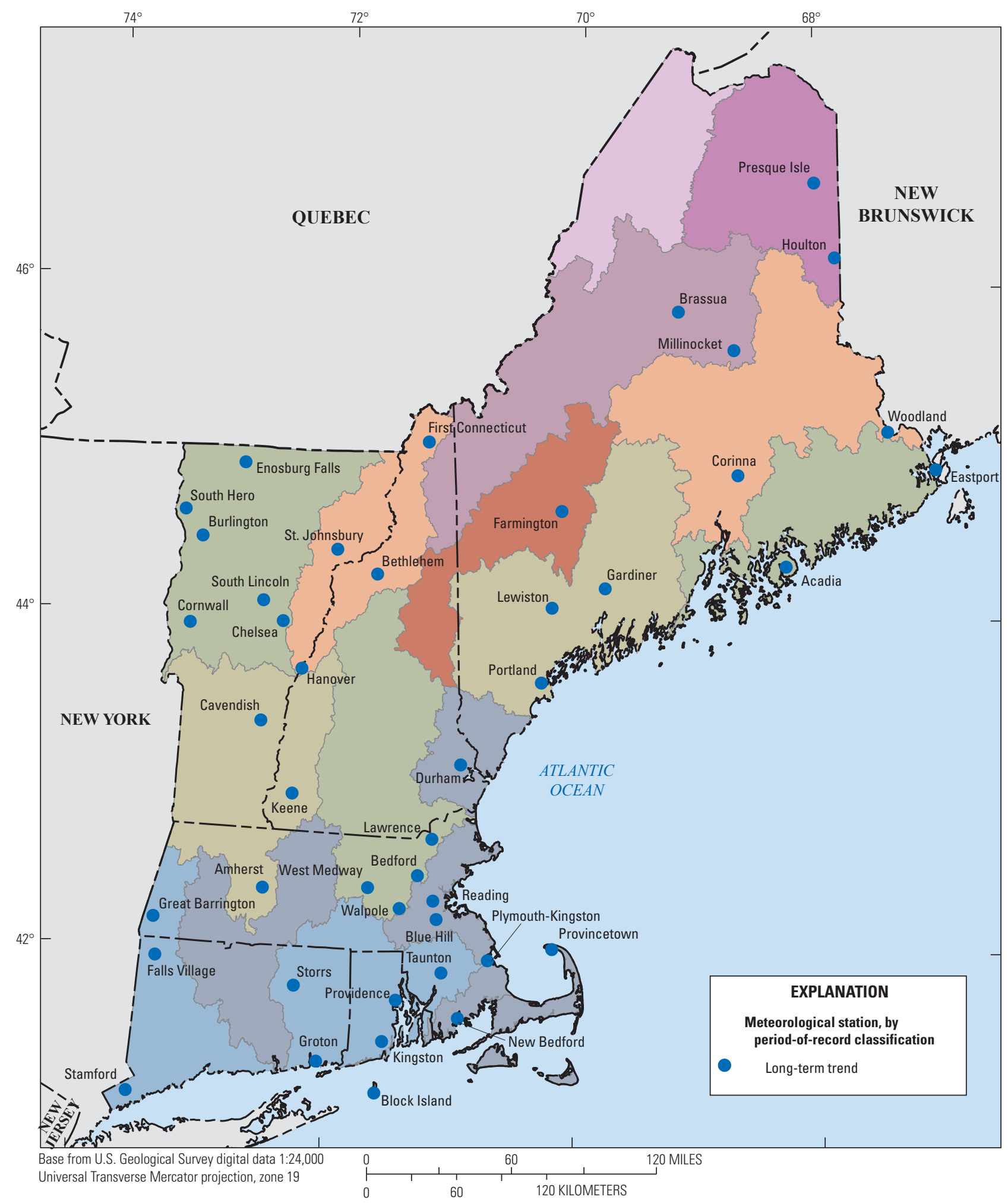

Figure 11. U.S. Historical Climatology Network meteorological stations in New England. Stations have at least 50 years of records for long-term trend testing. See figure 3 for climate-response regions by color. See table 7 for full station names. 
Table 8. Basin sites appropriate for process-based studies.

[See figure 12 for basin locations. ME, Maine; NH, New Hampshire; MA, Massachusetts; RI, Rhode Island; CT, Connecticut; VT, Vermont]

\begin{tabular}{|c|c|}
\hline $\begin{array}{l}\text { Station } \\
\text { number }\end{array}$ & Station name \\
\hline 01010000 & St. John River at Ninemile Bridge, ME \\
\hline 01013500 & Fish River near Fort Kent, ME \\
\hline 01017060 & $\begin{array}{l}\text { Hardwood Brook below Glidden Brook near } \\
\text { Caribou, ME }\end{array}$ \\
\hline 01018035 & $\begin{array}{l}\text { Meduxnekeag River at Lowery Road near } \\
\text { Houlton, ME }\end{array}$ \\
\hline 01022500 & Narraguagus River at Cherryfield, ME \\
\hline 01027200 & North Branch Penobscot River near Pittston Farm, ME \\
\hline 01030500 & Mattawamkeag River near Mattawamkeag, ME \\
\hline 01031500 & Piscataquis River near Dover-Foxcroft, $\mathrm{ME}$ \\
\hline 01037380 & Ducktrap River near Lincolnville, ME \\
\hline 01038000 & Sheepscot River at North Whitefield, ME \\
\hline 01047000 & Carrabassett River near North Anson, ME \\
\hline 01052500 & Diamond River near Wentworth Location, NH \\
\hline 01054200 & Wild River at Gilead, ME \\
\hline 01064500 & Saco River near Conway, NH \\
\hline 01067950 & Kennebunk River near Kennebunk, ME \\
\hline 01073000 & Oyster River near Durham, NH \\
\hline 01078000 & Smith River near Bristol, NH \\
\hline 01095220 & Stillwater River near Sterling, MA \\
\hline 01117468 & Beaver River near Usquepaug, RI \\
\hline 01121000 & Mount Hope River near Warrenville, CT \\
\hline 01135300 & Sleepers River (Site W-5) near St. Johnsbury, VT \\
\hline 01137500 & Ammonoosuc River at Bethlehem Junction, $\mathrm{NH}$ \\
\hline 01142500 & Ayers Brook at Randolph, VT \\
\hline 01150900 & Ottauquechee River near West Bridgewater, VT \\
\hline 01162500 & Priest Brook near Winchendon, MA \\
\hline 01181000 & West Branch Westfield River at Huntington, MA \\
\hline 01208990 & Saugatuck River near Redding, CT \\
\hline 01333000 & Green River at Williamstown, MA \\
\hline 04296000 & Black River at Coventry, VT \\
\hline
\end{tabular}

figure 12. Specific effort would be made to select candidate basins that have existing watershed models and ones that contain important resources such as Atlantic salmon habitat and (or) Native American and U.S. Department of Interior or Agriculture lands. A deterministic watershed model would then be developed for each of these basins (if not already completed) to improve understanding of basin hydrologic processes. The watershed models would use numerical methods to describe the physical processes that control the movement of water throughout a basin. Runoff processes simulated by the models would include overland flow, shallow subsurface flow, and groundwater flow.

The watershed models would be constructed by using the USGS Precipitation-Runoff Modeling System (PRMS; Leavesley and others, 1983; Markstrom and others, 2008). PRMS is well suited for simulating runoff from rural basins and has been applied to many basins in the United States. PRMS is a deterministic, distributed-parameter modeling system. The model is deterministic in that it computationally incorporates multiple components of the hydrologic cycle as understood through known physical laws or empirical relations in hydrologic science. The modeled hydrologic relations are typically governed by quantifiable physical characteristics of the basin. Parameters describing the physical basin characteristics are assigned in a distributed fashion, representing the spatial variation (heterogeneity) in basin characteristics. In this manner, the model is designed to simulate the hydrologic system as realistically as possible.

The models would be calibrated to historical records. Calibrated watershed models provide simulated time series of daily streamflow for many locations throughout a basin. The models leverage limited streamflow-gaging-station data and provide a method for characterizing subbasin hydrology. An example of rainfall-runoff-model subareas for two basins in eastern coastal Maine (Dudley, 2008) is shown in figure 13. The model explicitly simulates the physical processes of surface runoff, subsurface flow, and groundwater flow and processes affecting soil moisture, snowpack accumulation and melt, and evapotranspiration. This information would enable natural-resource managers to characterize the timing and quantity of water moving through the basin to support many endeavors, including geochemical calculations, water-use assessment, river biota population dynamics modeling, and habitat modeling and assessment. It would also allow scenario testing for interactions between climate change and changes in water use and land use.

Additional research would be conducted to improve understanding of processes such as soil moisture dynamics, groundwater/surface-water interactions, ice dynamics, and hydrologic/ecological interactions that are important to habitats and species. For example, with improved availability of groundwater data, PRMS could be integrated with the USGS groundwater model MODFLOW in an application called GSFLOW (Markstrom and others, 2008) to support investigations of basin-scale groundwater and surfacewater resources. Using models to characterize the relative contributions of surface water and groundwater to streamflow throughout the basin would lead to an improved understanding of water quantity and quality and the effects of future hydrologic changes on ecosystems in the basin. 


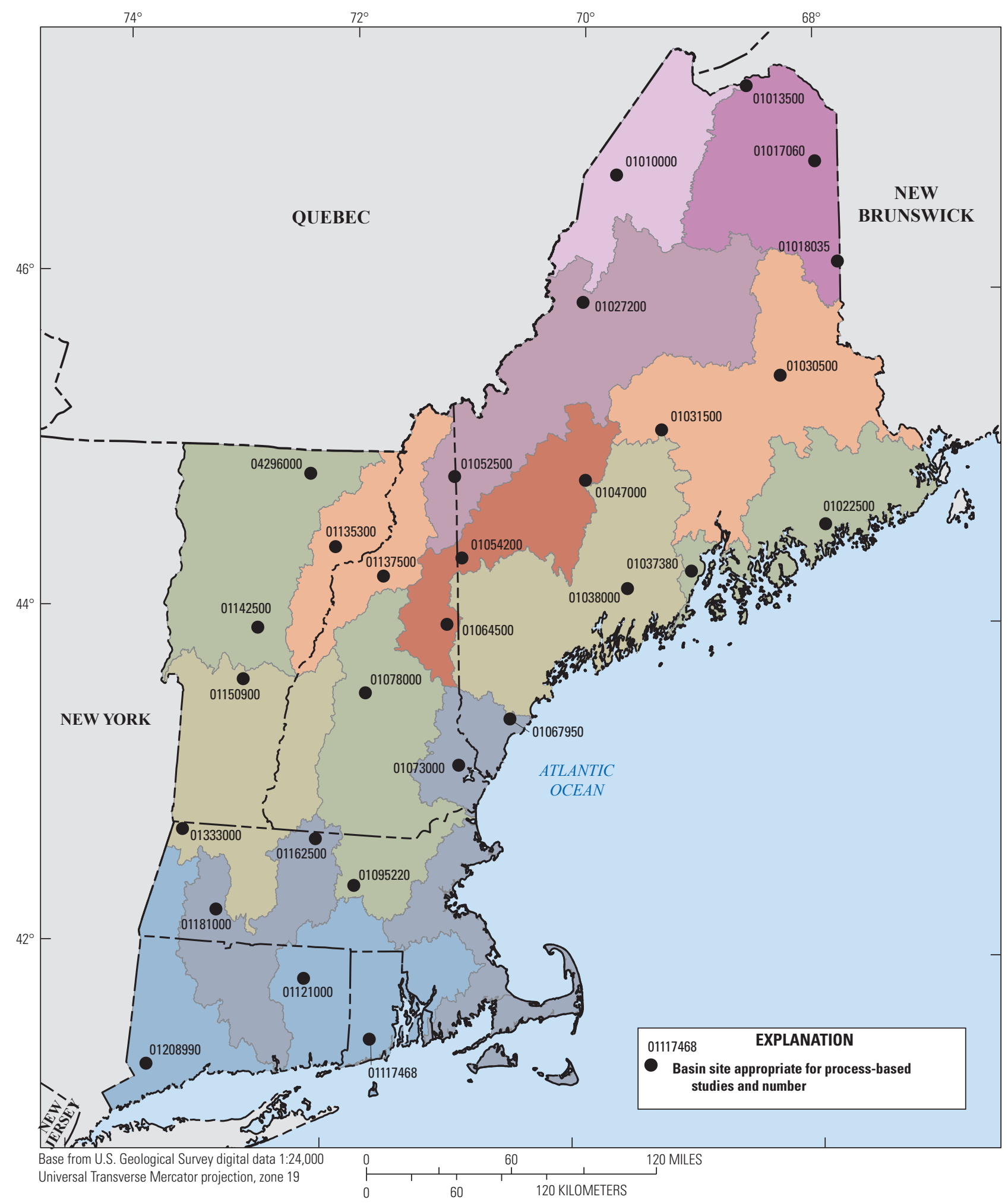

Figure 12. Basin sites appropriate for process-based studies. See figure 3 for climate-response regions by color. 


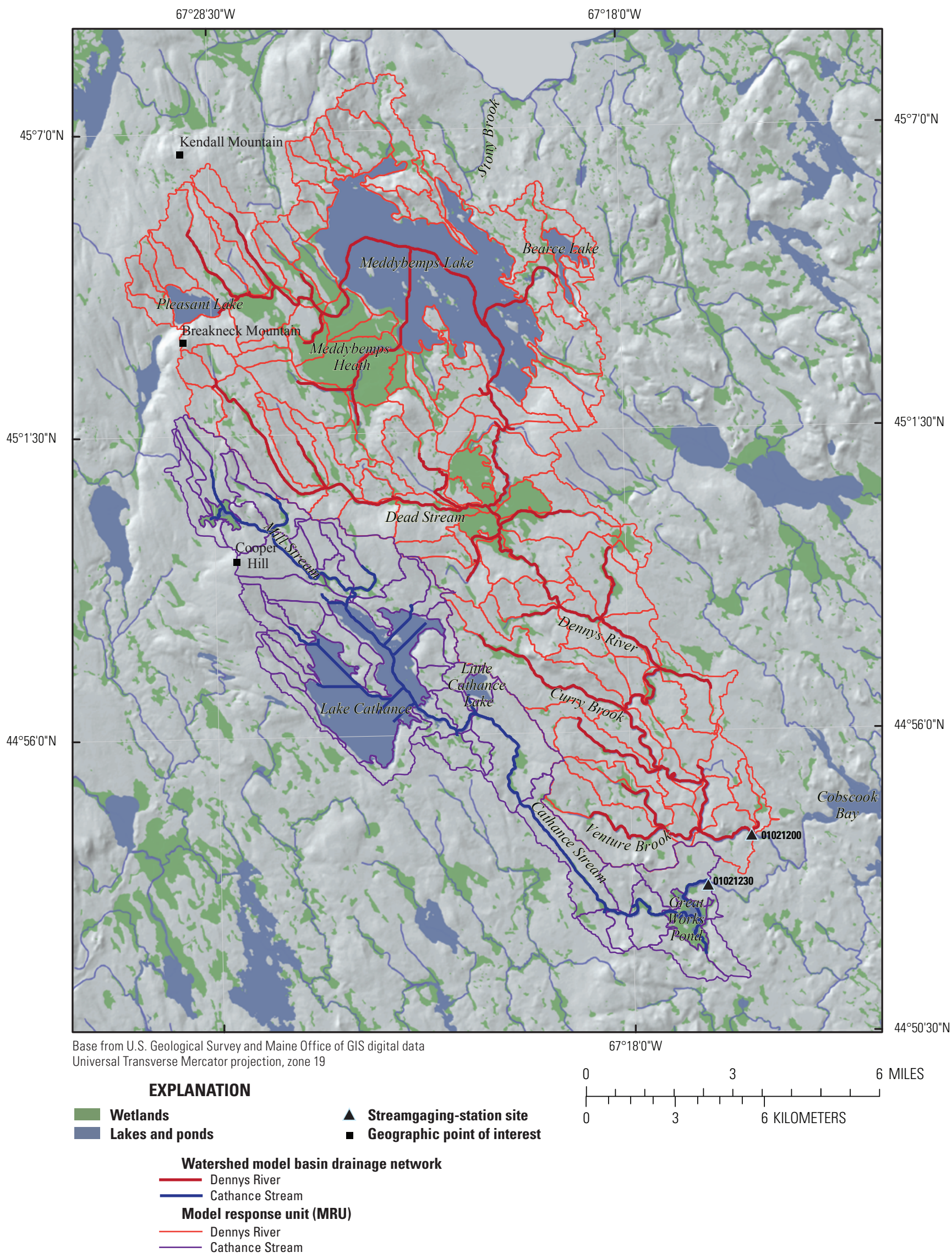

Figure 13. An example of rainfall-runoff-model subareas for two basins in eastern coastal Maine; modified from Dudley (2008, fig. 5). 


\section{Summary}

Seasonal, annual, and longer term variations in precipitation and air temperature can affect the timing and magnitudes of numerous hydrologic processes that, in turn, can affect human water supply, hydroelectric power generation, transportation infrastructure, and stream and riparian ecology. Recent investigations conclude that many different hydrologic processes in New England are sensitive to variations in precipitation and air temperature. Hydrologic variables such as peak flows, the timing of winter-spring flows, lake ice-out dates, snowpack, and groundwater levels have changed during the last century and are expected to change in the future. Many changes in winter and spring have been documented, and some changes in summer and fall and for annual flow variables have also been found. Observed trends during winter and spring are largely related to changes in air temperature because of the sensitivity of snowpack to air temperature changes in New England. Trends during summer and fall are largely related to changes in precipitation.

The framework for the New England climate-response network described in this report identifies specific inland hydrologic variables that are sensitive to climate variation; identifies geographic regions with similar hydrologic responses; proposes a fixed-station monitoring network that includes existing streamflow, groundwater, lake ice, snowpack, and meteorological data-collection networks for evaluation of hydrologic response to climate variation; and establishes potential streamflow basins for intensive process-based studies and for estimates of future hydrologic conditions.

The framework proposes that New England be divided into 14 regions that follow major river-basin boundaries, have relatively homogeneous climates, and contain network sites with similar values or trends in key hydrologic variables. Establishing the proposed network would require the identification of hydrologic components of interest (fluxes and storage compartments), the key variables that characterize each component, and a set of data-collection sites. Three criteria were used to identify key variables: the existence of long-term historical data, the expectation that a variable will be responsive to changes in precipitation and (or) air temperature during the next several decades, and the human or ecological importance of the component variables.

For the streamflow component, two key variables are proposed: winter-spring streamflow timing and the magnitude of the annual peak flow. Streamflow data proposed for New England are from rivers, monitored by U.S. Geological Survey streamflow-gaging stations, with streamflows minimally affected by direct changes to the watershed from human activities such as reservoir regulation and urbanization. Thirtyone streamflow-gaging stations in New England meet the criteria for minimal disturbance and long-term completeness (at least 80-percent data completeness for each decade from 1960 to 2013 (11 of 13 years for 2000 to 2012). Another 30 stations in New England meet the criteria for minimal disturbance and have shorter or less complete records.

Key variables for a groundwater network include the annual highest and lowest levels. For New England groundwater wells, a completeness criterion of 80 percent per decade yields 70 and 12 wells appropriate for short-term (30-year) and long-term (50-year) trend testing, respectively.

The key (and only commonly available in New England) historical measure of lake ice is lake ice-out date - the annual date in spring when winter ice cover leaves a lake. There are 37 lakes that meet long-term-completeness criteria (as defined in the previous paragraph). As of 2012, 5 lakes have 165 years or more of data, and another 14 have more than 110 years of data.

Key snowpack variables are the magnitude of latewinter water equivalent, depth, and density for selected dates. Twenty-three sites with long-term data for at least one late-winter sampling window were considered appropriate for a New England hydrologic climate-response network; data from these sites did not show significant sampling bias over time. It would be desirable to have additional snowpack sites outside of Maine, particularly in areas of regular substantial snowpack.

Precipitation and air temperature trends and variability are important to streamflow, groundwater, lake ice-out, and snowpack trends and variability. The relative influence of precipitation and air temperature varies by season. A network of 44 meteorological stations have a minimum of 99 years of record through 2012 and are appropriate for analyzing longterm trends.

An important part of establishing a hydrologic climateresponse network in New England is identifying basins that are appropriate for use in process-based studies designed to improve understanding of and predict hydrologic and ecosystem change. For each region in the proposed hydrologic climate-response network, a representative basin (in geology, land cover, and other characteristics) that has extensive historical data for multiple hydrologic components would be identified. A deterministic watershed model would then be developed for each of these basins (if not already completed). The models would then be used to improve understanding of hydrologic processes in basins (fluxes and storages), make streamflow projections, and provide input to ecological models.

This proposed framework for a New England climateresponse network lays a foundation for the organization of data-collection networks and climate-response regions and for the identification of key climate-related hydrologic variables. Ongoing and future analyses of hydrologic data are expected to inform improvements to the proposed framework. 


\section{References Cited}

Armstrong, W.H., Collins, M.J., and Snyder, N.P., 2012, Increased frequency of low-magnitude floods in New England: Journal of the American Water Resources Association, v. 48, no. 2, p. 306-320.

Beltaos, Spyros, 2002, Effects of climate on mid-winter ice jams: Hydrological Processes, v. 16, no. 4, p. 789-804.

Benson, B.J., Magnuson, J.J., Jensen, O.P., Card, V.M., Hodgkins, G.A., Korhonen, Johanna, Livingstone, D.M., Stewart, K.M., Weyhenmeyer, G.A., and Granin, N.G., 2012, Extreme events, trends and variability in Northern Hemisphere lake ice phenology (1855-2005): Climatic Change, v. 112, p. 299-323.

Bjerklie, D.M., Hay, L.E., and Markstrom, S.L., 2012, Watershed scale response to climate change-Pomperaug River watershed, Connecticut: U.S. Geological Survey Fact Sheet 2011-3122, 6 p. [Also available at http://pubs.usgs.gov/ fs $/ 2011 / 3122 /$.

Bjerklie, D.M., Trombley, T.J., and Viger, R.J., 2011, Simulations of historical and future trends in snowfall and groundwater recharge for basins draining to Long Island Sound: Earth Interactions, v. 15, no. 34, p. 1-35.

Blenckner, Thorsten, Omstedt, Anders, and Rummukainen, Markku, 2002, A Swedish case study of contemporary and possible future consequences of climate change on lake function: Aquatic Sciences, v. 64, no. 2, p. 171-184.

Blenckner, Thorsten, Pettersson, Kurt, and Padisák, Judit, 2002, Lake plankton as a tracer to discover climate signals: Verhandlungen des Internationalen Verein Limnologie, v. 28, p. 1324-1327.

Brooks, R.T., 2009, Potential impacts of global climate change on the hydrology and ecology of ephemeral freshwater systems of the forests of the northeastern United States: Climatic Change, v. 95, p. 469-483.

Cember, R.P., and Wilks, D.S., 1993, Climatological atlas of snowfall and snow depth for the northeastern United States and southeastern Canada: Northeast Regional Climate Center Research Publication RR 93-1, 213 p.

Collins, M.J., 2009, Evidence for changing flood risk in New England since the late 20th century: Journal of the American Water Resources Association, v. 45, no. 2, p. 279-290.

Corbett, D.M., and others, 1943, Stream-gaging procedure-A manual describing methods and practices of the Geological Survey: U.S. Geological Survey Water-Supply Paper 888, 245 p. [Also available at http://pubs.er.usgs.gov/publication/ wsp888.]
Douglas, E.M., and Fairbanks, C.A., 2011, Is precipitation in northern New England becoming more extreme? Statistical analysis of extreme rainfall in Massachusetts, New Hampshire, and Maine and updated estimates of the 100-year storm: Journal of Hydrologic Engineering, v. 16, no. 3 , p. 203-217.

Dudley, R.W., 2008, Simulation of the quantity, variability, and timing of streamflow in the Dennys River Basin, Maine, by use of a precipitation-runoff watershed model: U.S. Geological Survey Scientific Investigations Report 2008-5100, 44 p. [Also available at http://pubs.usgs.gov/ $\operatorname{sir} / 2008 / 5100 /$.

Dudley, R.W., Hay, L.E., Markstrom, S.L., and Hodgkins, G.A., 2012, Watershed scale response to climate changeCathance Stream Basin, Maine: U.S. Geological Survey Fact Sheet 2011-3128, 6 p. [Also available at http://pubs. usgs.gov/fs/2011/3128/.]

Dudley, R.W., and Hodgkins, G.A., 2002, Trends in streamflow, river ice, and snowpack for coastal river basins in Maine during the 20th century: U.S. Geological Survey Water-Resources Investigations Report 02-4245, 26 p. [Also available at http://me.water.usgs.gov/reports/wrir024245.pdf.]

Dudley, R.W., and Hodgkins, G.A., 2005, Trends in timing, magnitude, and duration of summer and fall/winter streamflows for unregulated coastal river basins in Maine during the 20th century: U.S. Geological Survey Scientific Investigations Report 2005-5021, 26 p. [Also available at http://pubs.usgs.gov/sir/2005/5021/.]

Dudley, R.W., and Hodgkins, G.A., 2013, Historical groundwater trends in northern New England and relations with streamflow and climatic variables: Journal of the American Water Resources Association, v. 49, no. 5, p. 1198-1212.

Elo Aija-Riitta, Huttula, Timo, Peltonen, Anu, and Virta, Juhani, 1998, The effects of climate change on the temperature conditions of lakes: Boreal Environment Research, v. 3, p. 137-150.

Falcone, J.A., 2011, GAGES-II-Geospatial attributes of gages for evaluating streamflow: U.S. Geological Survey Web page, accessed August 5, 2014, at http://water.usgs. gov/GIS/metadata/usgswrd/XML/gagesII_Sept2011.xml.

Frumhoff, P.C., McCarthy, J.J., Melillo, J.M., Moser, S.C., and Wuebbles, D.J., 2007, Confronting climate change in the U.S. northeast - Science, impacts, and solutions: Cambridge, Mass., Union of Concerned Scientists, 146 p. [Also available at http:/www.ucsusa.org/sites/default/files/ legacy/assets/documents/global_warming/pdf/confrontingclimate-change-in-the-u-s-northeast.pdf.] 
Grover, N.C., 1937, The floods of March 1936-Part 1. New England rivers: U.S. Geological Survey Water-Supply Paper 798, 466 p. [Also available at http://pubs.usgs.gov/ wsp/0798/report.pdf.]

Hayhoe, Katharine, Wake, C.P., Huntington, T.G., Luo, Lifeng, Schwartz, M.D., Sheffield, Justin, Wood, Eric, Anderson, Bruce, Bradbury, James, DeGaetano, Art, Troy, T.J., and Wolfe, David, 2007, Past and future changes in climate and hydrological indicators in the US northeast: Climate Dynamics, v. 28 , no. 4 , p. 381-407.

Hodgkins, G.A., 2010a, Historical changes in annual peak flows in Maine and implications for flood-frequency analyses: U.S. Geological Survey Scientific Investigations Report 2010-5094, 38 p. [Also available at http://pubs.usgs.gov/ sir/2010/5094/.]

Hodgkins, G.A., 2010b, Historical ice-out dates for 29 lakes in New England, 1807-2008: U.S. Geological Survey OpenFile Report 2010-1214, 32 p. [Also available at http://pubs.usgs.gov/of/2010/1214/.]

Hodgkins, G.A., 2013, The importance of record length in estimating the magnitude of climatic changes-An example using 175 years of lake ice-out dates in New England: Climatic Change, v. 119, nos. 3-4, p. 705-718.

Hodgkins, G.A., and Dudley, R.W., 2005, Changes in the magnitude of annual and monthly streamflows in New England, 1902-2002: U. S. Geological Survey Scientific Investigations Report 2005-5135, 37 p. [Also available at http://pubs.usgs.gov/sir/2005/5135/.]

Hodgkins, G.A., and Dudley, R.W., 2006a, Changes in latewinter snowpack depth, water equivalent, and density in Maine, 1926-2004: Hydrological Processes, v. 20, no. 4, p. $741-751$.

Hodgkins, G.A., and Dudley, R.W., 2006b, Changes in the timing of winter-spring streamflows in eastern North America, 1913-2002: Geophysical Research Letters, v. 33, no. 6, L06402, 5 p., http://dx.doi.org/10.1029/2005GL025593.

Hodgkins, G.A., and Dudley, R.W., 2011, Historical summer base flow and stormflow trends for New England rivers: Water Resources Research, v. 47, no. 7, W07528, 16 p., http://dx.doi.org/10.1029/2010WR009109.

Hodgkins, G.A., and Dudley, R.W., 2013, Modeled future peak streamflows in four coastal Maine rivers: U.S. Geological Survey Scientific Investigations Report 2013-5080, 18 p. [Also available at http://pubs.usgs.gov/sir/2013/5080/.]

Hodgkins, G.A., Dudley, R.W., and Huntington, T.G., 2003, Changes in the timing of high river flows in New England over the 20th century: Journal of Hydrology, v. 278, p. 244-252.
Hodgkins, G.A., Dudley, R.W., and Huntington, T.G., 2005a, Changes in the number and timing of days of ice-affected flow on northern New England rivers, 1930-2000: Climatic Change, v. 71, no. 3, p. 319-340.

Hodgkins, G.A., Dudley, R.W., and Huntington, T.G., 2005b, Summer low flows in New England during the 20th century: Journal of the American Water Resources Association, v. 41, no. 2 , p. $403-412$.

Hodgkins, G.A., Dudley, R.W., and Loiselle, M.C., 2005, Historical late-winter and spring snowpack depth and equivalent water-content data for Maine: U.S. Geological Survey Open-File Report 2005-1259, 80 p. [Also available at http://pubs.usgs.gov/of/2005/1259/.]

Hodgkins, G.A., Dudley, R.W., and Schalk, L.F., 2012, Relations between winter climatic variables and April streamflows in New England and implications for summer streamflows: U.S. Geological Survey Scientific Investigations Report 2012-5092, 11 p. [Also available at http://pubs.usgs.gov/sir/2012/5092/.]

Hodgkins, G.A., and James, I.C., II, 2002, Historical ice-out dates for 29 lakes in New England: U.S. Geological Survey Open-File Report 02-34, 32 p. [Also available at http://me.water.usgs.gov/reports/OFR02-34.pdf.]

Hodgkins, G.A., James, I.C., II, and Huntington, T.G., 2002, Historical changes in lake ice-out dates as indicators of climate change in New England, 1850-2000: International Journal of Climatology, v. 22, no. 15, p. 1819-1827.

Hodgkins, G.A., Lent, R.M., Dudley, R.W., and Schalk, C.W., 2009, Framework for a U.S. Geological Survey hydrologic climate-response program in Maine: U.S. Geological Survey Open-File Report 2009-1115, 23 p. [Also available at http://pubs.usgs.gov/of/2009/1115/.]

Huntington, T.G., Hodgkins, G.A., and Dudley, R.W., 2003, Historical trend in river ice thickness and coherence in hydroclimatological trends in Maine: Climatic Change, v. 61 , nos. $1-2$, p. $217-236$.

Huntington, T.G., Hodgkins, G.A., Keim, B.D., and Dudley, R.W., 2004: Changes in the proportion of precipitation occurring as snow in New England (1949-2000). Journal of Climate, v. 17, no. 13, p. 2626-2636.

Jassby, A.D., Powell, T.M., and Goldman, C.R., 1990, Interannual fluctuations in primary production-Direct physical effects and the trophic cascade at Castle Lake, California: Limnology and Oceanography, v. 35, no. 5, p. 1021-1038.

Juanes, Francis, Gephard, Stephen, and Beland, K.F., 2004, Long-term changes in migration timing of adult Atlantic salmon (Salmo salar) at the southern edge of the species distribution: Canadian Journal of Fisheries and Aquatic Sciences, v. 61, p. 2392-2400. 
Karl, T.R., and Knight, R.W., 1998, Secular trends of precipitation amount, frequency, and intensity in the United States: Bulletin of the American Meteorological Society, v. 79, p. 231-241.

Karl, T.R., Williams, C.N., Jr., Young, P.J., and Wendland, W.M., 1986, A model to estimate the time of observation bias associated with monthly mean maximum, minimum and mean temperatures for the United States: Journal of Climate and Applied Meteorology, v. 25, p. 145-160.

Kenny, J.F., Barber, N.L., Hutson, S.S., Linsey, K.S., Lovelace, J.K., and Maupin, M.A., 2009, Estimated use of water in the United States in 2005: U.S. Geological Survey Circular 1344, 52 p. [Also available at http://pubs.usgs.gov/ circ/1344/.]

Kirshen, Paul, Watson, Chris, Douglas, Ellen, Gontz, Allen, Lee, Jawon, and Tian, Yong, 2008, Coastal flooding in the northeastern United States due to climate change: Mitigation and Adaptation Strategies for Global Change, v. 13 , nos. 5-6, p. 437-451.

Leavesley, G.H., Lichty, R.W., Troutman, B.M., and Saindon, L.G., 1983, Precipitation-runoff modeling systemUser's manual: U.S. Geological Survey Water-Resources Investigations Report 83-4238, 207 p. [Also available at http://pubs.usgs.gov/wri/1983/4238/report.pdf.]

Lins, H.F., 2012, USGS hydro-climatic data network 2009 (HCDN-2009): U.S. Geological Survey Fact Sheet 2012-3047, 4 p. [Also available at http://pubs.usgs.gov/ fs $/ 2012 / 3047 /$.

Loiselle, M.C., and Hodgkins, G.A., 2002, Snowpack in Maine-Maximum observed and March 1 mean equivalent water content: U.S. Geological Survey Water-Resources Investigations Report 01-4258, 19 p. [Also available at http://me.water.usgs.gov/reports/WRIR01-4258.pdf.]

Markstrom, S.L., Hay, L.E., Ward-Garrison, C.D., Risley, J.C., Battaglin, W.A., Bjerklie, D.M., Chase, K.J., Christiansen, D.E., Dudley, R.W., Hunt, R.J., Koczot, K.M., Mastin, M.C., Regan, R.S., Viger, R.J., Vining, K.C., and Walker, J.F., 2012, Integrated watershed-scale response to climate change for selected basins across the United States: U.S. Geological Survey Scientific Investigations Report 2011-5077, 143 p. [Also available at http://pubs.usgs.gov/ $\operatorname{sir} / 2011 / 5077 /$.

Markstrom, S.L., Niswonger, R.G., Regan, R.S., Prudic, D.E., and Barlow, P.M., 2008, GSFLOW-Coupled ground-water and surface-water flow model based on the integration of the precipitation-runoff modeling system (PRMS) and the modular ground-water flow model (MODFLOW-2005): U.S. Geological Survey Techniques and Methods, book 6, chap. D1, 240 p. [Also available at http://pubs.usgs.gov/tm/ $\operatorname{tm} 6 \mathrm{~d} 1 /$.
Mastin, M.C., Chase, K.J., and Dudley, R.W., 2011, Changes in spring snowpack for selected basins in the United States for different climate-change scenarios: Earth Interactions, v. 15 , p. $1-18$.

McCormick, S.D., Hansen, L.P., Quinn, T.P., and Saunders, R.L., 1998, Movement, migration, and smolting of Atlantic salmon (Salmo salar): Canadian Journal of Fisheries and Aquatic Sciences, v. 55, supplement 1, p. 77-92.

Menne, M.J., and Williams, C.N., Jr., 2009, Homogenization of temperature series via pairwise comparisons: Journal of Climate, v. 22, p. 1700-1717.

Menne, M.J., Williams, C.N., Jr., and Vose, R.S., 2009, The United States historical climatology network monthly temperature data, version 2: Bulletin of the American Meteorological Society, v. 90, p. 993-1007.

Nakićenović, Nebojša, Alcamo, Joseph, Davis, Gerald, de Vries, Bert, Fenhann, Joergen, Gaffin, Stuart, Gregory, Kenneth, Grübler, Arnulf, Jung, T.Y., Kram, Tom, La Rovere, E.L., Michaelis, Laurie, Mori, Shunsuke, Morita, Tsuneyuki, Pepper, William, Pitcher, Hugh, Price, Lynn, Riahi, Keywan, Roehrl, Alexander, Rogner, H.H., Sankovski, Alexei, Schlesinger, Michael, Shukla, Priyararshi, Smith, Steven, Swart, Robert, van Rooijen, Sascha, Victor, Nadejda, and Zhou Dadi, 2000, Special report on emissions scenarios; A special report of Working Group III of the Intergovernmental Panel on Climate Change: Cambridge, United Kingdom, Cambridge University Press, 599 p. [Also available at http://www. grida.no/publications/other/ipcc $\% 5 \mathrm{Fsr} /$ ?src=/climate/ipcc/ emission/index.htm.]

National Oceanic and Atmospheric Administration, 2014, Mean sea level trends for northern Atlantic stations: National Oceanic and Atmospheric Administration data, accessed October 27, 2014, at http://tidesandcurrents.noaa. gov/sitrends/northatlantictrends.htm.

New England Regional Assessment Group, 2001, Preparing for a changing climate-The potential consequences of climate variability and change-The New England regional assessment overview: Durham, N.H., U.S. Global Change Research Program, 96 p. [Also available at http://downloads.globalchange.gov/nca/nca1/NCA1-New-EnglandAssessment-Report.pdf.]

Nielsen, M.G., and Dudley, R.W., 2013, Estimates of future inundation of salt marshes in response to sea-level rise in and around Acadia National Park, Maine: U.S. Geological Survey Scientific Investigations Report 2012-5290, 20 p. [Also available at http://pubs.usgs.gov/sir/2012/5290/.] 
Nõges, Tiina, Nõges, Peeter, Jolma, Ari, and Kaitaranta, Joni, 2009, Impacts of climate change on physical characteristics of lakes in Europe: Luxembourg, European Commission Joint Research Centre Report EUR 24064 EN, 56 p. [Also available at http://bookshop.europa.eu/en/impacts-ofclimate-change-on-physical-characteristics-of-lakes-ineurope-pbLBNA24064/.]

Poore, R.Z., Williams, R.S., Jr., and Tracey, Christopher, 2000, Sea level and climate: U.S. Geological Survey Fact Sheet 2000-002, 2 p. [Also available at http://pubs.usgs.gov/fs/ fs $2-00 /$.

Porter, K.G., Saunders, P.A., Haberyan, K.A., Macubbin, A.E., Jacobsen, T.R., and Hodson, R.E., 1996, Annual cycle of autotrophic and heterotrophic production in a small, monomictic Piedmont Lake (Lake Oglethorpe)_-Analog for the effects of climatic warming on dimictic lakes: Limnology and Oceanography, v. 41, no. 5, p. 1041-1051.

Power, G., Cunjak, R.A., Flannagan, J.F., and Katopodis, C., 1993, Biological effects of river ice, chap. 4 of Prowse, T.D., and Gridley, N.C., eds., Environmental aspects of river ice: Saskatoon, Saskatchewan, Environment Canada, National Hydrology Research Institute, p. 97-119.

Prowse, T.D., 1994, Environmental significance of ice to streamflow in cold regions: Freshwater Biology, v. 32, no. 2, p. 241-259.

Prowse, T.D., and Beltaos, Spyros, 2002, Climatic control of river-ice hydrology-A review: Hydrological Processes, v. 16 , no. 4 , p. 805-822.

Quinlan, F.T., Karl, T.R., and Williams, C.N., Jr., 1987, United States historical climatology network (HCN) serial temperature and precipitation data: Oak Ridge, Tenn., U.S. Department of Energy, Oak Ridge National Laboratory, NDP-019.
Rantz, S.E., and others, 1982, Measurement and computation of streamflow: U.S. Geological Survey Water-Supply Paper 2175, 2 v. [Also available at http://pubs.usgs.gov/wsp/ wsp2175/.]

Scrimgeour, G.J., Prowse, T.D., Culp, J.M., and Chambers, P.A., 1994, Ecological effects of river ice breakup-A review and perspective: Freshwater Biology, v. 32, no. 2, p. 261-275.

Sloto, R.A., and Crouse, M.Y., 1996, HYSEP_-A computer program for streamflow hydrograph separation and analysis: U.S. Geological Survey Water-Resources Investigations Report 96-4040, 46 p. [Also available at http://pubs.er.usgs. gov/publication/wri964040.]

Stefan, H.G., Hondzo, Midhat, and Fang, Xing, 1993, Lake water quality modeling for projected future climate scenarios: Journal of Environmental Quality, v. 22, no. 3, p. $417-431$.

Vose, R.S., Williams, C.N., Jr., Peterson, T.C., Karl, T.R., and Easterling, D.R., 2003. An evaluation of the time of observation bias adjustment in the U.S. historical climatology network: Geophysical Research Letters, v. 30, no. 20, p. CLM-3-1-CLM-3-4.

Weider, Kaitlyn, and Boutt, D.F., 2010, Heterogeneous water table response to climate revealed by 60 years of ground water data: Geophysical Research Letters, v. 37, no. 24, p. 1-6.

Wuebben, J.L., Deck, D.S., Zufelt, J.E., and Tatinclaux, J-C., 1995, Ice jam flood assessment for the St. John River Basin, Aroostook County, Maine: U.S. Army Corps of Engineers Special Report 95-15, 22 p. [Also available at http://www.dtic.mil/cgi-bin/GetTRDoc?AD=ADA295607.] 
For more information concerning this report, contact: Director, New England Water Science Center U.S. Geological Survey

196 Whitten Road

Augusta, ME 04330

dc_nweng@usgs.gov

or visit our Web site at:

http://me.water.usgs.gov

Publishing support by:

The Pembroke Publishing Service Center. 


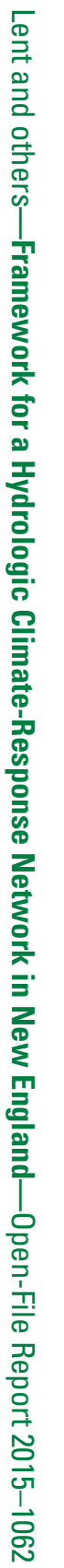

